\title{
Adaptation to Climate Change in the Hindu Kush Himalaya: Stronger Action Urgently Needed
}

\author{
Coordinating Lead Authors \\ Arabinda Mishra, International Centre for Integrated Mountain Development (ICIMOD), Nepal, \\ e-mail: Arabinda.Mishra@icimod.org (corresponding author) \\ Arivudai Nambi Appadurai, World Resources Institute (WRI-India), India, e-mail: Nappadurai@wri.org \\ Dhrupad Choudhury, International Centre for Integrated Mountain Development (ICIMOD), Nepal, \\ e-mail: Dhrupad.Choudhury@icimod.org
}

\section{Lead Authors}

Bimal Raj Regmi, Oxford Policy Management Limited, Nepal, e-mail: bimal.regmi@opml.co.uk Ulka Kelkar, World Resources Institute (WRI-India), India, e-mail: ulka.kelkar@gmail.com Mozaharul Alam, UN Environment, Regional Office for the Asia and Pacific, Thailand, e-mail: alam31@un.org

Pashupati Chaudhary, Agriculture and Forestry University (AFU), Rampur, Nepal,

e-mail: pashupatic@hotmail.com; pashupati.nature@gmail.com

Seinn Seinn Mu, Department of Agriculture, Ministry of Agriculture, Livestock and Irrigation, Myanmar, e-mail: seinnmu@gmail.com

Ahsan Uddin Ahmed, Centre for Global Change (CGC), Bangladesh, e-mail: ahsan.ua@gmail.com Hina Lotia, Leadership for Environment \& Development (LEAD) Pakistan, e-mail: hlotia@lead.org.pk Chao Fu, UN Environment International Ecosystem Management Partnership (UNEP-IEMP), China, e-mail: chao.fu@unep-iemp.org

Thinley Namgyel, National Environment Commission (NEC), Bhutan, e-mail: tn@ nec.govt.bt Upasna Sharma, Department of Humanities and Social Sciences, Indian Institute of Technology Delhi, India, e-mail: upasna@iitd.ac.in; upasna.sharma@gmail.com

\section{Contributing Authors}

Luni Piya, Graduate School for International Development and Cooperation (IDEC), Hiroshima University, Japan, e-mail: loonypiya@ hotmail.com

Sreeja Nair, School of Social Sciences, Nanyang Technological University, Singapore, e-mail: sreeja.nair@u.nus.edu

Navarun Varma, Residential College 4, National University of Singapore, e-mail: navarun@nus.edu.sg Chandra Sekhar Bahinipati, Department of Humanities and Social Sciences, Indian Institute of Technology Tirupati, India, e-mail: csbahinipati@iittp.ac.in; csbahinipati@gmail.com

Jyoti Nair, Ashoka Trust for Research in Ecology and the Environment (ATREE), India, e-mail: jyoti.nair@atree.org

Kamal Aryal, International Centre for Integrated Mountain Development (ICIMOD), Nepal, e-mail: Kamal.Aryal@icimod.org

Basharat Ahmed Saeed, Leadership for Environment \& Development (LEAD) Pakistan,

e-mail: Basharat.a.saeed@gmail.com

Umama Binte Azhar, Leadership for Environment \& Development (LEAD) Pakistan,

e-mail: umamabinteazhar@gmail.com

\section{Review Editor}

Asuncion Lera St.Clair, DNV GL, Norway, and Senior Advisor, Earth Systems Services, Barcelona Super Computer Center, Spain, e-mails: Asun.Lera.St.Clair@dnvgl.com; asun.lerastclair@bsc.es

\section{Corresponding Author}

Arabinda Mishra, International Centre for Integrated Mountain Development (ICIMOD), Nepal, e-mail: Arabinda.Mishra@icimod.org 


\section{Contents}

Chapter Overview.

13.1 Adaptation to Climate Change: Stronger Action Urgently Needed

13.1.1 Adaptation to Climate Change in the HKH: A Complex Challenge Compounded by Social Differentiation and Poor Development.

13.1.2 Response of HKH National Governments to Adaptation Challenges, and Influence of Evolving Global Regime

13.2 Local Autonomous Responses to Climate Variability and Extreme Events in HKH 467

13.2.1 Many Autonomous Adaptation Practices Remain Very Relevant Locally and Need Policy Support ....

13.2.2 Autonomous Adaptation May Be Unable to Manage New Risks and 'Surprises' from Climate Change

13.2.3 Local Adaptation Knowledge Merits Greater Attention from Science and Policy .............. 470

13.3 State-Led Planned Adaptation in the HKH

13.3.1 Commonalities Among Policy Responses of National Governments......

13.3.2 HKH Countries Have High-Level Polities to Coordinate Decentralized Government Action on Climate Change.

13.3.3 Public Consultation and Stakeholder Engagement in Adaptation Planning and Implementation Is Very Uneven Among the HKH Countries

13.3.4 Limited Tailored Response to Gender and Social Inclusion............................................... 476

13.3.5 Implementing Adaptation Programmes Is Challenged by Institutional Inertia and Inadequate Institutional Capacity

13.4 Adaptation Initiatives by Non-state Actors Shaping Practice in the HKH.

13.4.1 Multiple Actors and Approaches, but Little Synergy.

13.4.2 Scaling up and Sustainability: Challenges Common to Projects Implemented by NGOs..

13.5 Financing Adaptation in the HKH 479

13.5.1 HKH-Specific Estimates of Funding Need and Availability for Climate Change Adaptation Are Absent..

13.5.2 Business Potential in Adaptation Is High, but Investment Is Limited.

13.5.3 Opportunity to Build Adaptive Capacity from Labour Migration and Migrant Remittances.

13.6 The Way Forward-Key Areas for Priority Action by HKH Country Governments ............ 482

13.6.1 Regional Cooperation on Adaptation Is Essential ......................................................... 482

13.6.2 Stronger Integration of Adaptation in Development Plans and Programmes...................... 483

13.6.3 Convergence of Adaptation, DRR, SDGs, and Resilience-Building Priorities..................... 483

13.6.4 Investing to Enhance Synergies Between CBA and EBA .................................................... 483

13.6.5 Generating New Knowledge and Boosting Climate Literacy .............................................. 484

13.6.6 A Policy Environment for Social Learning ....................................................................... 484

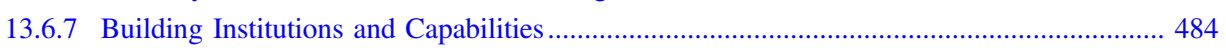

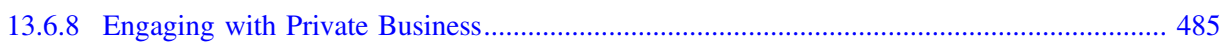

13.6.9 Engaging with the Emerging Policy Regime on Loss and Damage.................................... 485 


\section{Chapter Overview}

\section{Key Findings}

1. Adaptation to climate change is increasingly urgent for the HKH-yet for policy makers it is a complex challenge. Adaptation responses by governments in the HKH are mostly incremental and not yet well integrated with development plans and programmes. Especially at the subnational level, action suffers from poor understanding of existing autonomous responses, as well as insufficient resources, climate information, and clear adaptation options.

2. In spite of these challenges, opportunities do exist for a scaled up, inclusive, and more comprehensive climate change adaptation responses in the HKH. Such opportunities may include improved regional cooperation among $\mathrm{HKH}$ countries, incentives to promote policy experimentation, initiatives to develop climate literacy, and enhanced private sector engagement.

3. Bolstering climate change adaptation in the HKH will require very substantial increases in funding than currently available. As climate change funding filters down from international and national sources to local government and community levels, the funding loses its "identity" as adaptation finance. With appropriate incentive mechanisms, private financing also might support adaptation.

\section{Policy Messages}

1. Climate change adaptation policies and practices must intensify in the $\mathrm{HKH}-$ and must become transformative. Lessons learned from successful policy instruments, such as the Local Adaptation Plans for Action (LAPAs), should widely inform efforts elsewhere. Governments will benefit from mainstreaming these instruments in their planning and budgeting processes. Institutional capacity on adaptation needs to increase until it fits to purpose at each level of governance.

2. Local-level autonomous responses to climate variability and extreme events must be systematically studied, documented, and validated. Such responses need to generate critical, practice-based feedback for adaptation planning at higher governance levels.
3. HKH countries and institutions must work together to build mechanisms and fora to debate and negotiate key challenges, such as data sharing, and to incentivize regional cooperation and cross-learning at a regional scale. This cooperation is needed to harness relevant opportunities, expertise and experiences.

Climate change impacts in the mountains of the HKH are already substantive. Increased climate variability is already affecting water availability, ecosystem services, and agricultural production, and extreme weather is causing flash floods, landslides, and debris flow. Climate change is likely to have serious effects in the next decades in the mountains of the $\mathrm{HKH}$ (well established). By 2050, mountain temperatures across the region are projected to increase beyond $2{ }^{\circ} \mathrm{C}$ on average, and more at higher elevations. Mountain communities - especially remote ones - are more vulnerable to climate change impacts than non-mountain areas (established but incomplete). The high mountains are poorly served by life-saving and livelihood-supporting infrastructure. Access to climate information and support services is limited, as is the presence of government extension agencies. Weak institutional links hinder farmers from adopting technology that can contribute to adaptive capacity. For poor and marginalized groups, deep and pervasive structural inequalities make climate change adaptation even more difficult. Although the IPCC Fifth Assessment Report Working Group 2 had four chapters on adaptation, literature on mountain specifics was not prioritized. However, although still insufficient, scientific literature in the region is rapidly emerging, and there is a wealth of information emerging from ongoing adaptation action driven by $\mathrm{HKH}$ countries.

This chapter focuses primarily on analysing ongoing adaptation activities and identifying common patterns of adaptation response across the eight countries with territory in the HKH-Afghanistan, Bangladesh, Bhutan, China, India, Myanmar, Nepal, and Pakistan. The chapter distinguishes between adaptation responses that are planned by governments or by non-state actors, and those that are local and autonomous, unplanned. Further, it asks whether the planned responses are sufficiently knowledgeable of autonomous adaptation practices, and it considers the extent of policy support for these practices as well as the need to critically evaluate practices and results. Autonomous adaptation is key in the HKH because it draws on local knowledge systems, recognized as repositories of traditions and management practices that can usefully inform adaptation responses. Yet the systematic documentation of local, autonomous responses 
to climate change in the HKH is limited, and few attempts have been made to validate these responses scientifically.

Policy makers in the HKH countries are aware of the urgency to act on adaptation but face substantive challenges (well established). Some of those challenges are a lack of adequate data (both in terms of quantity and quality, and especially at a localized scale) about climate change impacts, weak institutional capacity at various governance levels, social and economic barriers to intervention uptake, and poor infrastructure for development and adaptation purposes.

The chapter finds that government-led planned adaptation responses in the $\mathrm{HKH}$ are strongly influenced by the evolving global regime under the United Nations Framework Convention on Climate Change (UNFCCC). Notably, the National Adaptation Plan (NAP) process - established in 2010 - emphasizes that to reduce vulnerability and build resilience, countries should integrate climate change adaptation into development planning. This assessment shows that all HKH countries have initiated efforts towards such integration, and established high-level coordinating bodies under political leadership. The government-led responses are at both national and subnational levels through multiple plans, programmes, and projects. In all the countries there is clear identification of priority sectors for adaptation interventions; however, attention to mountain specificities is not common (well established).

Planned responses to climate change by HKH governments and non-state actors are hindered by large constraints on institutional capacity (well established) leading to major gaps between policy goals and actual implementation of adaptation programmes. This chapter seeks to identify the most urgent of these constraints - the ones that require immediate action. It also describes many adaptation initiatives undertaken by non-state actors. How can one learn from the most successful of these initiatives, be replicated and scaled up, to inform and create synergies with other coordinated actions? The chapter identifies solutions that could work to better connect adaptation science, policy, and practice.

Given climate change impacts are likely to be substantial in the near future-even though they may be nonlinear and subject to high uncertainty-HKH countries will benefit from moving beyond incremental strategies (established but incomplete) and scale up transformative adaptation, integrating these with development planning and disaster risk reduction. Assessment of the scientific literature, adaptation policy and action by non-state actors shows there is a large potential for enhanced opportunities through investments for generating science-based climate information and knowledge services, as well as incentives to promote policy experimentation through adaptation pilots. Institutional capacity building on adaptive governance and the creation of knowledge networks are also important. Greater regional cooperation among $\mathrm{HKH}$ countries in information and knowledge sharing, particularly in areas such as disaster risk reduction, and food and water security is of critical importance.

There is need for stronger integration of adaptation with national development plans and programmes, including with the ongoing implementation of the Sustainable Development Goals (SDGs). Gaps in a country's adaptive capacity cannot be addressed until political leadership pushes for an intensified adaptation response within the larger development regime. It is also critical to enhance regional collaboration, and substantively increase adaptation finance, including mobilization of funds for greater social protection and risk insurance. Engagement of the private sector in adaptation to climate change and resilience is a critical factor for successful action.

The chapter concludes by putting forward a measurable set of HKH mountain targets consistent with the SDGs, and proposes an SDG-consistent priority for the HKH region on adaptation: Ensure integration between adaptation to climate change, disaster risk reduction, and sustainable development for the mountains through evidence-based decision making and means of implementation.

\section{Climate Change Adaptation and the SDGs}

HIMAP puts forward a vision for meeting the SDGs in the $\mathrm{HKH}$ region. Adaptation to climate change cuts across multiple SDGs (and most HIMAP priorities) and, given climate change impacts in the HKH region, is a necessary condition for socio-ecological resilience. It also deserves specific attention as the result of integrated action with development planning and DRR. First, enhancing resilience in HKH ecosystems, communities, human settlements, and urban areas is intrinsically related to ending poverty in all its forms, ensuring nutrition, access to energy and water, enhanced livelihoods, and freedom from all forms of inequality (in particular gender inequalities). This requires a combination of autonomous and transformative adaptation options, strategically embedded in all development trajectories and in close collaboration with all forms of DRR. Autonomous adaptation builds on ongoing adaptive practices that, without explicit planning, increase adaptive capacity. At the same time, there is a need for transformational adaptation, changing systems and behaviour to generate inclusive change, rather than coping only with climate impacts. There is an urgent need for policy approaches that are pro-poor, socially inclusive, and well integrated with DRR and other resilience-building interventions, while also being forward looking, seeking co-benefits and attentive to trade-offs with the wider sustainable development agenda.

Adaptation to climate change needs to contribute to promoting sustainable production systems to assure food 
security, nutrition security, and income for mountain people, with particular attention to women's changing roles in agriculture. This encompasses SDGs 2, 5, 6, 7, 9, and 11. Clearly, SDG 13-Take urgent action to combat climate change and its impacts - is a central SDG for adaptation to climate change. For the HKH, target 13.2: Integrate climate change measures into national policies, strategies and planning is of utmost relevance, and the NAP process can be very effective in this regard.

Further, this assessment experience leads us to pay close attention to SDG 16-Promote peaceful and inclusive societies for sustainable development, provide access to justice for all, and build effective, accountable, and inclusive institutions at all levels. Target 16.7: Ensure responsive, inclusive, participatory and representative decision-making at all levels is of particular importance. Inclusive institutions are essential in the HKH for adaptation measures to be consistent with social justice.

Finally, SDG 17-Strengthen the means of implementation and revitalize the global partnership for sustainable development-includes target 17.6, stressing the need for enhanced regional and international cooperation as well as partnerships with non-state actors, such as business and industry. Adaptation to climate change in the HKH will depend on meeting this target, for practical reasons related to financing, technology transfer, and capacity building.

We propose an SDG-consistent priority for adaptation to climate change in the HKH:

- Ensure integration between adaptation to climate change, and DRR and sustainable development for the mountains, through evidence-based decision making and means of implementation.

To materialize this goal, and drawing from the lessons learned in this assessment, we propose 10 indicators of climate change adaptation for the $\mathrm{HKH}$, consistent with SDG priorities and targets, to guide policy makers in implementing the SDG framework in the region:

1. Number of deaths, missing persons, and persons affected by climate hazards per 100,000 people (disaggregated by sex)

2. Economic loss (as a percentage of national GDP) that is averted by climate-proofing critical infrastructure and basic services

3. Percentage of population with access to improved climate information and services
4. Percentage of population with improved access to successful adaptation technologies

5. Proportion of local governments that formulate and implement local adaptation plans aimed at DRR and resilience building for vulnerable population groups

6. Number of cities or urban settlements with access to safe, climate-resilient infrastructure and service delivery systems

7. Percentage of rural population drawing a major part of their household income from climate-resilient livelihood systems

8. Amount of climate financing flowing locally for climate change adaptation (for example, the percentage of the national budget allocated to mountain districts)

9. Access to international funding (for example, from the Green Climate Fund)

10. Number of knowledge institutions actively engaged in adaptation knowledge generation, communication, pilots, and scale-up relevant to the mountain context.

\subsection{Adaptation to Climate Change: Stronger Action Urgently Needed}

Temperature across the mountains of the HKH is projected to increase by about $1-2{ }^{\circ} \mathrm{C}$ by 2050 , and by even more at higher elevations (Shrestha et al. 2015). Winters are expected to grow warmer at a faster rate than summers in most places. Precipitation projections are less certain and the spatial variability is high (see Chap. 3). The likely increase in frequency and magnitude of extreme weather events such as high intense rainfall leading to flash floods, landslides, and debris flow (Shrestha et al. 2015) can have serious consequences. These events would most likely affect various productive sectors in the HKH countries, particularly the natural resources systems that provide the livelihoods for poor and marginal communities, and impede the development process (Ahmed and Suphachalasai 2014; Moors and Stoffel 2013; Su et al. 2013). There is also the recognition that climate-related population dislocation will be significant in Bangladesh, China, India, and Pakistan (ADB 2012).

The current level of understanding of adaptation needs and interventions specific to mountain situations continues to be highly limited because of inadequate knowledge of climate change impacts on mountain people and ecosystems. At the same time, adaptation is becoming increasingly urgent for 
the HKH. A number of research studies (as cited in earlier chapters of this volume) show that increased climate variability is already affecting water availability, ecosystem services, and agricultural production in the region. The huge impact of frequent extreme weather events on life and property in the region underscores the urgency of the situation and the necessity to ramp up adaptation action there.

Five of the eight HKH countries-Afghanistan, Bhutan, Myanmar, Nepal, and Pakistan — are predominantly mountain countries and, at the same time, four of these (excluding Pakistan) are classified as Least Developed Countries (LDCs). Even in case of the remaining two South Asian countriesBangladesh and India - the mountain states/regions compare poorly with most of their non-mountain counterparts in terms of GDP and human development index (HDI) indicators. In China, most people living in poverty reside in mountain regions that occupy nearly two-thirds of the land. ${ }^{1}$ Thus, for mountain people in HKH countries, climate change impacts carry a significant risk of undermining the achievement of fundamental human rights such as those to food, health, adequate housing, and access to safe drinking water and sanitation (Cameron et al. 2013).

While climate change is acting as a natural driver of change, there are several other driving forces such as population change, economic growth, urbanization, and globalization (see Chap. 2) causing rapid socioeconomic transformation in the HKH. This process of change is often accompanied by conditions of high uncertainty due to complex interactions among the driving forces. For adaptation planning and actions under circumstances of large-scale changes (some of which may be nonlinear) and high uncertainty, the HKH countries are required to go beyond incremental strategies and initiate transformative development and adaptation. An example of transformational change urgently required in the $\mathrm{HKH}$ is enabling mountain women, left behind because of male out-migration, to emerge from being 'frontline victims' of climate change impacts to become 'risk and resource managers' with control over productive assets (Mishra et al. 2017a). There is definitely a capacity need for policy makers in the HKH to plan and deliver such change, but addressing this need will be possible only when the political leadership pushes for an intensification of the adaptation responses within a larger transformative development regime.

\section{Box 13.1 Approach to this assessment}

This assessment seeks to identify patterns in adaptation response common to the eight HKH countriesAfghanistan, Bangladesh, Bhutan, China, India,

\footnotetext{
${ }^{1}$ http://www.fao.org/docrep/ARTICLE/WFC/XII/0510-A3.HTM.
}

Myanmar, Nepal, and Pakistan. We look at both autonomous and planned adaptation responses to climate change impacts. In the "planned" category we seek to distinguish between government responses and initiatives taken by non-government actors. We try to understand to what extent adaptation policy formulation is learning from autonomous practices; and, vice versa, we ask to what extent autonomous adaptation is receiving policy support-especially in the case of mountain people's farm-based activities that are of key importance to rural livelihoods in the HKH. In the case of planned adaptation, institutional capacity constraints are many and we seek to identify those that require urgent attention. Adaptation practice in the $\mathrm{HKH}$ is dominated by many disconnected activities and initiatives, often mostly proposing incremental change. The question is how to move beyond such fragmentation, and beyond incremental action, to replicate, scale up, and create synergies from mutual learning and coordinated action. This requires transformative approaches that truly generate integrated results with development planning and DRR activities.

\subsubsection{Adaptation to Climate Change in the HKH: A Complex Challenge Compounded by Social Differentiation and Poor Development}

The mountain communities in HKH countries, particularly those located in remote areas, are most vulnerable to climate change impacts (especially disasters caused by extreme weather events). The adaptation needs of several subsets of highly vulnerable groups in the $\mathrm{HKH}$ - such as indigenous peoples, women, migrants and migrant-sending households, urban slum dwellers, and minorities-deserve special understanding and targeted action. Deep and pervasive structural inequalities in HKH societies make adaptation even more difficult for poor and marginalized people. Entitlements to elements of adaptive capacity (for example, ownership of productive assets and access to services of local government agencies) are typically socially differentiated, and this affects the uptake of coping strategies. For instance, in studies conducted in the central and western mountains of Nepal, caste hierarchy and patriarchy-led gender restrictions have been found to act as barriers for socially marginalized groups within a locality to access certain institutions and adopt the adaptation options that are easily accessible to the so-called higher castes (Jones and Boyd 2011; Onta and Resurreccion 2011). For HKH policy 
makers, such social embeddedness makes adaptation a complex challenge.

The other key constraints to adaptive capacity building of the HKH mountain communities arise because of low availability of relevant scientific information and limited access to climate information and support services. Connectivity through internet and mobile phone services, although improving over time, is still inadequate and not universal in the hill and mountain areas of the region. Because of the difficult terrain, government extension agencies have sparse presence and weak outreach in most parts of the HKH geographical area. Poor information flows and weak support from the extension system results in poor adoption among farmers of new and innovative adaptation measures.

Similar to the thin presence of agricultural extension services in mountain regions, the level of penetration of life- and livelihood-supporting infrastructure is considerably lower in high mountainous terrains compared to other areas within HKH countries. Adaptation measures for infrastructure assets in vital sectors such as transportation, water storage, irrigation, energy, and urban utilities are lacking. Lack of investment in this regard has long remained a challenge in the HKH. The investment bottleneck must be addressed by the leadership of these countries, in order to dent the prevailing development injustice, so that people in the HKH can use such infrastructure and accrue adaptation benefits.

\subsubsection{Response of HKH National Governments to Adaptation Challenges, and Influence of Evolving Global Regime}

The emergence of adaptation as a response option within the UNFCCC has been marked by several milestones. The first significant action towards adaptation started in 2001 with the establishment of the LDC Expert Group to provide technical support to the LDCs for preparing their National Adaptation Programmes of Action (NAPA); and with the establishment of the LDC Fund and the Special Climate Change Fund (SCCF) to support LDCs and developing countries, respectively, with adaptation action. This was followed by a knowledge and networking platform to support adaptation under the Nairobi Work Plan in 2005. The Adaptation Fund was launched in 2007 under the Kyoto Protocol to fund adaptation action in developing countries under a novel "direct-financing" modality. The Cancun Adaptation Framework in 2010 further increased the focus on adaptation under the UNFCCC process with the establishment of the Adaptation Committee and the launch of the process to formulate and implement National Adaptation Plans (NAPs) for LDCs and other developing countries. Most recently the Paris Agreement in 2015 cemented adaptation under Article 7 which defines an adaptation goal, the approach towards adaptation at the national level, and also provides for "adaptation communications" by parties to submit their priorities and needs for adaptation.

The NAP process established in 2010 emphasizes that reducing vulnerability and building climate resilience requires the integration of adaptation planning with overall development planning. This is further carried into the Paris Agreement with the adaptation goal of "enhancing adaptive capacity, strengthening resilience and reducing vulnerability to climate change, with a view to contributing to sustainable development". 2 All the HKH countries have included adaptation actions in their Nationally Determined Contributions (NDCs), ${ }^{3}$ and the majority have explicitly identified the NAP process as the approach for adaptation (Table 13.1).

In their NDCs, some HKH countries emphasize building synergy between climate action and achieving the SDGs. For instance, Myanmar's climate change strategy and action plan identifies adaptation indicators that are linked with the SDG targets in sectors such as health, climate change, biodiversity, and food security. Similarly, Nepal's NDC states that it is "imperative for Nepal to tackle the impact of poverty and climate change simultaneously to achieve Sustainable Development Goals" (p. 9). The NDCs of India and Pakistan also make emphatic reference to the SDG commitment. In its NDC, China has committed to embarking on a sustainable development path that encompasses economic development, social progress, and action on climate change.

Adaptation priorities, based on a review of UNFCCC documents submitted by HKH countries (NAPA, national communications, NDCs), commonly identify agriculture, water, health, forests and biodiversity, and disaster management as key sectors for intervention. Mountain-specific adaptation issues are observed to have received varying degrees of emphasis in country priorities. Thus, in the case of Bhutan (a wholly mountainous country) all its NAPA priorities relate to mountain-specific climate risks and vulnerabilities. Strengthening early-warning systems for floods and glacial lake outburst floods (GLOF) risk reduction are identified as requiring a significantly higher density of stations owing to micro-variation in the topography and climates in a mountain environment. Nepal's NAPA and Local Adaptation Plans of Action (LAPA) specifically recognized the key risks and vulnerabilities of fragile mountain ecosystems such as the rain shadow districts in the mid- and far-western region as the most vulnerable and prioritized the geographic areas for adaptation interventions. Another example of a mountain-specific policy response is India's National Mission for Sustaining the Himalayan Ecosystem, which is one of the eight missions under the country's

\footnotetext{
${ }^{2} \mathrm{https}: / /$ sustainabledevelopment.un.org/frameworks/parisagreement. ${ }^{3}$ All the HKH country NDCs are available at the public registry (interim) maintained by the UNFCCC Secretariat: http://www4.unfccc. int/ndcregistry/Pages/Home.aspx.
} 
Table 13.1 Summary of adaptation components given in Nationally Determined Contributions, by country

\begin{tabular}{|c|c|c|c|c|c|c|}
\hline Country & Adaptation vision/goal & $\begin{array}{l}\text { Status with respect to } \\
\text { NAPA \& NAP (or other } \\
\text { (sub)national policy } \\
\text { frameworks) }\end{array}$ & $\begin{array}{l}\text { Adaptation priorities (in } \\
\text { terms of sectors or } \\
\text { actions) }\end{array}$ & $\begin{array}{l}\text { Cost of adaptation } \\
\text { measures }\end{array}$ & $\begin{array}{l}\text { Target } \\
\text { years }\end{array}$ & $\begin{array}{l}\text { Date of } \\
\text { INDC } \\
\text { submission } \\
\text { to } \\
\text { UNFCCC }\end{array}$ \\
\hline Afghanistan & $\begin{array}{l}\text { "to protect the country and } \\
\text { its population by } \\
\text { enhancing adaptive } \\
\text { capacity and resilience, } \\
\text { effectively respond to the } \\
\text { vulnerabilities of critical } \\
\text { sectors, and efficiently } \\
\text { mainstream climate change } \\
\text { considerations into } \\
\text { national development } \\
\text { policies, strategies, and } \\
\text { plans" (p. 4) }\end{array}$ & $\begin{array}{l}\text { NAPA and NCSA } \\
\text { completed in } 2009 . \text { NAP } \\
\text { process under way }\end{array}$ & $\begin{array}{l}\text { - Development of the } \\
\text { CCSAP and } \\
\text { vulnerability monitoring } \\
\text { and assessment system } \\
\text { - Mainstreaming of } \\
\text { adaptation technologies } \\
\text { - Regional and } \\
\text { international } \\
\text { cooperation for } \\
\text { adaptation technology } \\
\text { transfer } \\
\text { - Meteorological and } \\
\text { hydrological monitoring } \\
\text { networks and services } \\
\text { - Water resources } \\
\text { infrastructure and } \\
\text { irrigation systems } \\
\text { - Community-based } \\
\text { natural resources } \\
\text { management } \\
\text { - Selected species and } \\
\text { habitat conservation } \\
\text { - Alternative and } \\
\text { renewable energy } \\
\text { - Regeneration of } \\
\text { degraded forests and } \\
\text { rangeland areas }\end{array}$ & $\begin{array}{l}\text { USD10.785 billion } \\
\text { (of a total financial } \\
\text { need of } \\
\text { USD17.405 } \\
\text { billion) }\end{array}$ & $2020-30$ & $\begin{array}{l}13 \text { October } \\
2015\end{array}$ \\
\hline Bangladesh & $\begin{array}{l}\text { "to protect the population, } \\
\text { enhance their adaptive } \\
\text { capacity and livelihood } \\
\text { options, and to protect the } \\
\text { overall development of the } \\
\text { country in its stride for } \\
\text { economic progress and } \\
\text { wellbeing of the people" } \\
\text { (p. 10) }\end{array}$ & $\begin{array}{l}\text { NAPA submitted in } 2005 \\
\text { (revised in 2009); NAP } \\
\text { roadmap prepared }\end{array}$ & $\begin{array}{l}\text { - Improved early warning } \\
\text { systems } \\
\text { - Disaster preparedness } \\
\text { and protection measures } \\
\text { - Climate-resilient } \\
\text { housing, infrastructure, } \\
\text { and communication } \\
\text { - Urban drainage } \\
\text { - River training and } \\
\text { dredging } \\
\text { - Stress-tolerant variety } \\
\text { improvement and } \\
\text { cultivation (including } \\
\text { livestock and fisheries) } \\
\text { - Research and knowledge } \\
\text { management } \\
\text { - Health } \\
\text { - Biodiversity and } \\
\text { ecosystem conservation } \\
\text { - Institutional capacity } \\
\text { building }\end{array}$ & $\begin{array}{l}\text { USD42 billion (of } \\
\text { a total financial } \\
\text { need of USD69 } \\
\text { billion) }\end{array}$ & $2015-30$ & $\begin{array}{l}25 \\
\text { September } \\
2015\end{array}$ \\
\hline Bhutan & $\begin{array}{l}\text { "to remain carbon neutral" } \\
\text { (p. 1) "Adaptation to } \\
\text { adverse impacts of climate } \\
\text { change is a priority" and is } \\
\text { to be pursued through } \\
\text { NAP towards "reducing } \\
\text { vulnerability by both } \\
\text { integrating climate change } \\
\text { adaptation into national } \\
\text { development planning and }\end{array}$ & $\begin{array}{l}\text { NAPA prepared in } 2006 \\
\text { and updated in } 2012 \text {; NAP } \\
\text { process to begin on receipt } \\
\text { of support }\end{array}$ & $\begin{array}{l}\text { - Water security through } \\
\text { IWRM } \\
\text { - Climate-resilient } \\
\text { agriculture and livestock } \\
\text { farming } \\
\text { - Sustainable forest } \\
\text { management and } \\
\text { conservation of } \\
\text { biodiversity }\end{array}$ & Costs not indicated & $\begin{array}{l}\text { 2018-23 } \\
\text { (actions } \\
\text { integrated } \\
\text { in 12th } \\
5 \text {-year } \\
\text { Plan) }\end{array}$ & $\begin{array}{l}30 \\
\text { September } \\
2015\end{array}$ \\
\hline
\end{tabular}


Table 13.1 (continued)

\begin{tabular}{|c|c|c|c|c|c|c|}
\hline Country & Adaptation vision/goal & $\begin{array}{l}\text { Status with respect to } \\
\text { NAPA \& NAP (or other } \\
\text { (sub)national policy } \\
\text { frameworks) }\end{array}$ & $\begin{array}{l}\text { Adaptation priorities (in } \\
\text { terms of sectors or } \\
\text { actions) }\end{array}$ & $\begin{array}{l}\text { Cost of adaptation } \\
\text { measures }\end{array}$ & $\begin{array}{l}\text { Target } \\
\text { years }\end{array}$ & $\begin{array}{l}\text { Date of } \\
\text { INDC } \\
\text { submission } \\
\text { to } \\
\text { UNFCCC }\end{array}$ \\
\hline & $\begin{array}{l}\text { also implementing priority } \\
\text { adaptation actions on the } \\
\text { ground" (p. 5) }\end{array}$ & & $\begin{array}{l}\text { - Resilience to climate } \\
\text { change-induced hazards } \\
\text { - Minimize climate- } \\
\text { related health risks } \\
\text { - Climate-proof transport } \\
\text { infrastructure } \\
\text { - Climate information } \\
\text { services for } \\
\text { vulnerability assessment } \\
\text { and adaptation planning } \\
\text { - Renewable and } \\
\text { climate-resilient energy } \\
\text { generation }\end{array}$ & & & \\
\hline China & $\begin{array}{l}\text { "to proactively adapt to } \\
\text { climate change by } \\
\text { enhancing mechanisms } \\
\text { and capacities to } \\
\text { effectively defend against } \\
\text { climate change risks in key } \\
\text { areas such as agriculture, } \\
\text { forestry and water } \\
\text { resources, as well as in } \\
\text { cities, coastal and } \\
\text { ecologically vulnerable } \\
\text { areas and to progressively } \\
\text { strengthen early warning } \\
\text { and emergency response } \\
\text { systems and disaster } \\
\text { prevention and reduction } \\
\text { mechanisms" (p. 5) }\end{array}$ & $\begin{array}{l}\text { National Strategy for } \\
\text { Climate Adaptation under } \\
\text { implementation }\end{array}$ & $\begin{array}{l}\text { Measures to enhance } \\
\text { overall climate } \\
\text { resilience: } \\
\text { - Safe operation of } \\
\text { infrastructure of water } \\
\text { conservancy, transport, } \\
\text { and energy against } \\
\text { climate change } \\
\text { - Optimal water resources } \\
\text { management } \\
\text { - Water conservation } \\
\text { facilities for farmlands, } \\
\text { to vigorously develop } \\
\text { water-saving } \\
\text { agricultural irrigation } \\
\text { and to cultivate heat- } \\
\text { and drought-resistant } \\
\text { crops } \\
\text { - Resilience of coastal } \\
\text { areas against climatic } \\
\text { disasters } \\
\text { - Track, monitor, and } \\
\text { assess the impact of } \\
\text { climate change on } \\
\text { biodiversity } \\
\text { - Strengthen forestry } \\
\text { infrastructure } \\
\text { - Effectively safeguard } \\
\text { urban infrastructure } \\
\text { - Contingency planning } \\
\text { and capacity building } \\
\text { for public health } \\
\text { services } \\
\text { - Improve early warning } \\
\text { and communication } \\
\text { - System } \\
\text { reduction and } \\
\text { emergency response } \\
\text { systems }\end{array}$ & Costs not indicated & By 2030 & $\begin{array}{l}30 \text { June } \\
2015\end{array}$ \\
\hline India & $\begin{array}{l}\text { "To better adapt to climate } \\
\text { change by enhancing } \\
\text { investments in } \\
\text { development programmes } \\
\text { in sectors vulnerable to }\end{array}$ & $\begin{array}{l}\text { NAPCC and SAPCC } \\
\text { under implementation }\end{array}$ & $\begin{array}{l}\text { The NDC estimate of } \\
\text { USD206 billion is for } \\
\text { implementing adaptation } \\
\text { actions in agriculture, } \\
\text { forestry, fisheries }\end{array}$ & $\begin{array}{l}\text { USD206 billion (at } \\
2014-15 \text { prices; } \\
\text { mitigation cost } \\
\text { estimated around } \\
\text { USD834 billion }\end{array}$ & $2015-30$ & $\begin{array}{l}1 \text { October } \\
2015\end{array}$ \\
\hline
\end{tabular}


Table 13.1 (continued)

\begin{tabular}{|c|c|c|c|c|c|c|}
\hline Country & Adaptation vision/goal & $\begin{array}{l}\text { Status with respect to } \\
\text { NAPA \& NAP (or other } \\
\text { (sub)national policy } \\
\text { frameworks) }\end{array}$ & $\begin{array}{l}\text { Adaptation priorities (in } \\
\text { terms of sectors or } \\
\text { actions) }\end{array}$ & $\begin{array}{l}\text { Cost of adaptation } \\
\text { measures }\end{array}$ & $\begin{array}{l}\text { Target } \\
\text { years }\end{array}$ & $\begin{array}{l}\text { Date of } \\
\text { INDC } \\
\text { submission } \\
\text { to } \\
\text { UNFCCC }\end{array}$ \\
\hline & $\begin{array}{l}\text { climate change, } \\
\text { particularly agriculture, } \\
\text { water resources, } \\
\text { Himalayan region, coastal } \\
\text { regions, health and disaster } \\
\text { management" (p. 29) }\end{array}$ & & $\begin{array}{l}\text { infrastructure, water } \\
\text { resources and ecosystems. } \\
\text { Additional investments } \\
\text { would be needed for } \\
\text { strengthening resilience } \\
\text { and disaster management } \\
\text { (p. 31) }\end{array}$ & $\begin{array}{l}\text { until } 2030 \text { at } 2011 \\
\text { prices) }\end{array}$ & & \\
\hline Myanmar & $\begin{array}{l}\text { "a vision for achieving } \\
\text { climate resilient, } \\
\text { low-carbon, resource } \\
\text { efficient and inclusive } \\
\text { development as a } \\
\text { contribution to sustainable } \\
\text { development" (p. 1) }\end{array}$ & $\begin{array}{l}\text { NAPA under } \\
\text { implementation since } \\
\text { 2012; NAP to be } \\
\text { developed }\end{array}$ & $\begin{array}{l}\text { NAPA priority sectors: } \\
\text { 1. Resilience in the } \\
\text { agriculture sector, } \\
\text { developing early-warning } \\
\text { systems, and forest } \\
\text { preservation measures } \\
\text { 2. Public health protection } \\
\text { and water resource } \\
\text { management } \\
\text { 3. Coastal zone protection } \\
\text { 4. Energy and industry } \\
\text { sectors, and biodiversity } \\
\text { preservation }\end{array}$ & Costs not indicated & $\begin{array}{l}\text { Not } \\
\text { indicated }\end{array}$ & $\begin{array}{l}28 \\
\text { September } \\
2015\end{array}$ \\
\hline Nepal & $\begin{array}{l}\text { "Nepal's Climate Change } \\
\text { Policy (2011) envisions a } \\
\text { country spared from the } \\
\text { adverse impacts of climate } \\
\text { change, by considering } \\
\text { climate justice, through the } \\
\text { pursuit of environmental } \\
\text { conservation, human } \\
\text { development, and } \\
\text { sustainable development } \\
\text {.. The Policy has } \\
\text { objectives of ... enhancing } \\
\text { the climate adaptation and } \\
\text { resilience capacity of local } \\
\text { communities for optimum } \\
\text { utilization of natural } \\
\text { resources and their efficient } \\
\text { management" (p. } 3 \text { ) }\end{array}$ & $\begin{array}{l}\text { NAPA prepared in } 2010 \text {; } \\
\text { LAPAs being implemented } \\
\text { in } 90 \text { village development } \\
\text { committees and } 7 \\
\text { municipalities, and nearly } \\
2,200 \text { CAPA for } \\
\text { community forests } \\
\text { developed; NAP } \\
\text { preparation ongoing since } \\
2015\end{array}$ & $\begin{array}{l}\text { - NAP formulation and } \\
\text { implementation; } \\
\text { implementation of } \\
\text { NAPA and LAPA } \\
\text { - Strengthening } \\
\text { implementation of } \\
\text { EFLG framework in } \\
\text { village development } \\
\text { committees and } \\
\text { municipalities to } \\
\text { complement climate } \\
\text { change adaptation } \\
\text { - Study of impacts of } \\
\text { climate change in } \\
\text { mountains, hills, and } \\
\text { lowland ecosystems and } \\
\text { landscapes } \\
\text { - Research into loss and } \\
\text { damage associated with } \\
\text { climate change impacts } \\
\text { - Sustainable management } \\
\text { of forests } \\
\text { - Agricultural sector } \\
\text { enhancement by } \\
\text { adopting } \\
\text { climate-friendly } \\
\text { technologies and } \\
\text { reducing climate change } \\
\text { impacts } \\
\text { - Climate-induced } \\
\text { disasters in } \\
\text { earthquake-affected } \\
\text { areas } \\
\text { captional-level building }\end{array}$ & Costs not indicated & $\begin{array}{l}\text { Varies } \\
\text { from sector } \\
\text { to sector }\end{array}$ & $\begin{array}{l}11 \\
\text { February } \\
2016\end{array}$ \\
\hline Pakistan & $\begin{array}{l}\text { "To build a climate } \\
\text { resilient society and } \\
\text { economy by ensuring that } \\
\text { climate change is }\end{array}$ & $\begin{array}{l}\text { Process of developing a } \\
\text { NAP under way }\end{array}$ & $\begin{array}{l}\text { Medium- to long-term } \\
\text { actions (to 2030): } \\
\text { - Improving irrigation } \\
\text { systems }\end{array}$ & $\begin{array}{l}\text { USD7-14 billion } \\
\text { per annum }\end{array}$ & $\begin{array}{l}\text { Medium to } \\
\text { long-term } \\
\text { actions (to } \\
2030 \text { ); }\end{array}$ & $\begin{array}{l}6 \\
\text { November } \\
2016\end{array}$ \\
\hline
\end{tabular}


Table 13.1 (continued)

\begin{tabular}{|c|c|c|c|c|c|c|}
\hline Country & Adaptation vision/goal & $\begin{array}{l}\text { Status with respect to } \\
\text { NAPA \& NAP (or other } \\
\text { (sub)national policy } \\
\text { frameworks) }\end{array}$ & $\begin{array}{l}\text { Adaptation priorities (in } \\
\text { terms of sectors or } \\
\text { actions) }\end{array}$ & $\begin{array}{l}\text { Cost of adaptation } \\
\text { measures }\end{array}$ & $\begin{array}{l}\text { Target } \\
\text { years }\end{array}$ & $\begin{array}{l}\text { Date of } \\
\text { INDC } \\
\text { submission } \\
\text { to } \\
\text { UNFCCC }\end{array}$ \\
\hline & $\begin{array}{l}\text { mainstreamed in the } \\
\text { economically and socially } \\
\text { vulnerable sectors of the } \\
\text { economy" (p. 15) }\end{array}$ & & $\begin{array}{l}\text { - Enhancing water } \\
\text { resource management } \\
\text { - Strengthening risk } \\
\text { management system for } \\
\text { the agriculture sector } \\
\text { - Implementing a } \\
\text { comprehensive } \\
\text { climate-smart } \\
\text { agriculture programme } \\
\text { - Building } \\
\text { climate-resilient } \\
\text { infrastructure (focus on } \\
\text { water) } \\
\text { - Improving the } \\
\text { emergency response } \\
\text { mechanism for } \\
\text { managing extreme } \\
\text { climate events and } \\
\text { strengthening the } \\
\text { development of disaster } \\
\text { reduction and relief } \\
\text { management systems } \\
\text { Near-term actions } \\
\text { (2020-25): } \\
\text { - Developing NAP } \\
\text { - Strengthening } \\
\text { subnational adaptation } \\
\text { planning capacity } \\
\text { Implementation of } \\
\text { actions under "National } \\
\text { Disaster Management } \\
\text { Plan" }\end{array}$ & & $\begin{array}{l}\text { near-term } \\
\text { actions } \\
(2020-25)\end{array}$ & \\
\hline
\end{tabular}

National Action Plan on Climate Change (NAPCC). It is the only mission with a geographical focus and its primary objective is to conserve biodiversity, forest cover, and other ecological values in the Himalaya by scientifically assessing the region's vulnerability to climate change.

\subsection{Local Autonomous Responses to Climate Variability and Extreme Events in HKH}

Autonomous adaptation by mountain communities to change in general has evolved over the ages (Jodha 1992) and can be applied to climate change. This capacity to adjust is based on possibly thousands of reactive (ad hoc, retrofitting, or retrospective) and proactive (anticipating, precautionary, incremental, or prospective) strategies to deal with climate variability and change, but very little is systematically researched and documented, and is specific to the HKH.

\subsubsection{Many Autonomous Adaptation Practices Remain Very Relevant Locally and Need Policy Support}

In response to climate risks, farmers in the $\mathrm{HKH}$ employ a number of reactive and proactive adaptation practices, such as those used by farmers in Nepal (Table 13.2).

Autonomous adaptation practices are rooted in a community's culture, tacit knowledge base, leadership, innovations, collective action, and experiential learning that are mediated by individuals and local institutions (Agrawal 
Table 13.2 Examples of reactive and proactive adaptation practices in the agricultural sector in Nepal

\begin{tabular}{|c|c|c|}
\hline Climate risk & Proactive/prospective adaptation & Reactive/retrospective adaptation \\
\hline $\begin{array}{l}\text { Temperature } \\
\text { rise }\end{array}$ & $\begin{array}{l}\text { - Mulching of crops to retain moisture } \\
\text { - Terrace wall farming to avert risk of crop failure and to } \\
\text { check evapotranspiration } \\
\text { - Farmer-managed irrigation systems, community-managed } \\
\text { drinking water systems, and traditional water mills } \\
\text { - Legume integration with maize }\end{array}$ & $\begin{array}{l}\text { - Changing cropping patterns in response to crop failure } \\
\text { following climate risks } \\
\text { - Introduction of new crops that did not grow well in the past } \\
\text { owing to excessive cold (e.g., apple and maize are being } \\
\text { introduced to new locations in Mustang) }\end{array}$ \\
\hline $\begin{array}{l}\text { Erratic rainfall } \\
\text { with frequent } \\
\text { drought }\end{array}$ & $\begin{array}{l}\text { - Dry seedbeds for sowing rice } \\
\text { - Introduction of drought-tolerant crops such as millet, } \\
\text { soybean, black gram } \\
\text { - Mixing drought-tolerant local varieties with improved } \\
\text { varieties of maize for risk distribution } \\
\text { - Varying the sowing dates in different plots for spatial risk } \\
\text { distribution in case of seasonal droughts }\end{array}$ & $\begin{array}{l}\text { - Direct seeding when drought damages crops } \\
\text { - Collection of wild edible foods } \\
\text { - Building adaptive local institutional structures to improve } \\
\text { distribution, allocation, and efficient use of water resources }\end{array}$ \\
\hline $\begin{array}{l}\text { Excessive } \\
\text { rainfall and } \\
\text { flooding }\end{array}$ & $\begin{array}{l}\text { - Raised seedbeds for nursery preparation } \\
\text { - Fencing land, orchards, houses } \\
\text { - Growing flood-tolerant crops } \\
\text { - Hedgerow plantations of deep-rooted grasses along the } \\
\text { contours of sloping agricultural lands to prevent loss of } \\
\text { topsoil and erosion }\end{array}$ & $\begin{array}{l}\text { - Altering planting time and methods (e.g., } \\
\text { double-transplanting of rice) when flood damages crops } \\
\text { - Migration to safer places }\end{array}$ \\
\hline Hailstones & $\begin{array}{l}\text { - Growing hailstone-tolerant crops such as turmeric, ginger, } \\
\text { garlic, onion, yam, cardamom, etc. }\end{array}$ & $\begin{array}{l}\text { - Replacing walnuts with almonds to reduce damage caused } \\
\text { by hailstones }\end{array}$ \\
\hline $\begin{array}{l}\text { Biophysical } \\
\text { damage }\end{array}$ & $\begin{array}{l}\text { - Shifting cultivation to cultivate less disrupted and } \\
\text { deteriorated lands on a rotational basis }\end{array}$ & $\begin{array}{l}\text { - Bamboo fencing to protect land, orchards, and houses } \\
\text { - Change of occupation, migration }\end{array}$ \\
\hline
\end{tabular}

2008; Smit and Pilifosova 2001). Examples of autonomous adaptation occurring in different sectors are discussed below to illustrate why and how some practices continue to be relevant and need policy support. Some sectors have more documented examples compared to others.

\section{Agriculture}

There is sufficient evidence from the HKH countries to conclude that farmers are already adopting a wide variety of autonomous strategies to adapt to a changing climate. To take a few examples:

- In Pakistan, because of increased uncertainty in rainfall patterns, farmers have begun to change their cropping calendar and in some cases have even altered crop varieties. Some field-level studies have documented this practice in some districts in Southern Punjab and Sindh and have written policy recommendations. ${ }^{4,5}$

- In China, drought is compelling farmers to choose a crop that can adapt to the stress, is multifunctional, and at the same time gives better economic returns under such

${ }^{4}$ http://www.lead.org.pk/lead/Publications/Thematic\%20Agriculture\% 20LAPA.pdf.

${ }^{5}$ http://www.lead.org.pk/lead/Publications/Thematic\%20Water\%

20LAPA.pdf. conditions. In addition, farmers are willing to increase investment in irrigation infrastructure and adopt water-saving technologies in response to climate change and the risk of increasing water scarcity (Wang et al. 2010).

- In hill and mountain districts of Nepal, mixing different varieties of beans and maize seeds is a very common risk-aversion strategy, because at least some of the genotypes survive extreme events and environmental stresses. Farmers also alter the sowing dates by a few days in different plots to distribute the risk of short-duration seasonal droughts during peak growing phases (Piya et al. 2012, 2013). People have developed different agroforestry practices to address frequent drought, landslides, and surface soil erosion, and have constructed cost-effective bamboo fencing to protect themselves from recurrent floods (ICIMOD 2007).

- In the hills of Uttarakhand, India, farmers respond to changes in rainfall by shifting to less water-intensive crops and diversifying their sources of livelihood (Kelkar et al. 2008). Farmers in Sikkim have introduced crops (such as maize, cabbage, pumpkin, and carrot) that were previously unable to grow at high altitudes (Ingty and Bawa 2012).

- In Myanmar's mountain areas traditional rotating fallow system or shifting cultivation is the common adaptation of farmers. Terrace farming and irrigated farming from water flow of natural springs are also autonomous adaptation of hill tribes in Northern Shan. 


\section{Livestock/Pastoral}

- Pastoral communities in Nepal have been using various reactive and proactive adaptation techniques, such as changing grazing areas and transhumant routes ${ }^{6}$ and reducing the length of stay at points en route when biophysical conditions deteriorate; stall-feeding animals, growing fodder and forage, reducing herd size, and feeding crop stubbles, by-products, and hay to livestock during dry periods to cope with shortage of feed; preserving native breeds that bear ecological stresses; digging ponds to store water for feeding animals; and moving animal sheds and houses or entire villages to new locations when people face or anticipate some ecological risks (Aryal et al. 2014; Banjade and Paudel 2008; Moktan et al. 2008).

- Pastoralists in Sikkim, India, have responded to changes in snowfall and rainfall by replacing sheep with yak, and by collectively banning the slaughter and sale of sheep for a few years (Ingty and Bawa 2012).

- In the Chinese context $\mathrm{Li}$ and Huntsinger (2011) observed how increasing land privatization and the institutionalization of rigid land tenure in the Inner Mongolia region have weakened traditional practices of pasture and herd management, and in the process reduced the resilience of pastoralists to cope with environmental crises like drought. The traditional common property regimes not only allowed for greater mobility over larger areas, which favoured the ecology of natural grasslands, but also offered the benefits of mutual aid and resource pooling (Cao et al. 2013).

\section{Water Resources}

- Water is emerging as the most important and pressing climate change impact in Bhutan, with drying sources being reported in many parts of the country (NEC 2011). Norbu and Kusters (2012) reported that small-scale farmers in Punakha Valley were coping with insufficient water for irrigation from traditional sources by pumping rivers.

- In the hills of Nepal, villagers have constructed community-managed water tanks sourced from free-flowing natural springs for water storage and use during recurring dry seasons, which are reported to have intensified in recent years (Piya et al. 2012, 2013). However, with springs drying up, such a practice is at risk of losing relevance and possible alternatives may not be immediately clear to communities.

\footnotetext{
${ }^{6} \mathrm{~A}$ transhumance system is a strong institution developed to govern animal movements (redirection), prairie management, and rationalization of resources use in response to or anticipated biophysical and ecological changes.
}

- In areas of northern Pakistan, glaciers provide water through slope-side channels. To overcome water deficiency local people practise artificial glacier grafting to create new glaciers. ${ }^{7}$

\section{Forests}

- A community forestry programme in Nepal has mobilized communities to manage forest resources in a sustainable way. ${ }^{8}$ Communities have adopted numerous practices to sustainably manage and benefit from the forest ecosystems, especially in times of stress such as crop failures and droughts.

\section{Disasters}

- Over the last few years, long and recurrent droughts in Nepal are making a vast tract of land untended, ultimately leading to substantive yield reduction in several districts across the country. People have responded by migrating to nearby urban centres. Labour migration is a prominent way of diversifying livelihoods and securing a source of income that is not affected by difficult local conditions and shocks.

- In Sikkim, India, indigenous communities are coping with erratic rainfall and unseasonal floods and landslides by using local ecological knowledge and traditional techniques like riverbank retaining walls, terracing, and stabilizing slopes with native plants and rocks (Ingty and Bawa 2012).

\section{Urban Settlements}

- Recent research indicates that the urban poor (for example, slum dwellers) are aware of the adversities of climate change and are willing to undertake measures to mitigate the impacts. An example comes from outside the $\mathrm{HKH}$ region. In El Salvador, people living in 15 disaster-prone slum areas invested at considerable cost to themselves in multiple strategies aimed at risk reduction, self-insurance and recovery (Wamsler 2007). Similarly, and closer to $\mathrm{HKH}$, the wealthier households in the cities of India, Pakistan, and Vietnam have been observed to

\footnotetext{
${ }^{7}$ http://lib.icimod.org/record/12783/files/1081.pdf.

${ }^{8}$ More than 25,000 community-based forest management groups across the country are directly engaged in managing about $30 \%$ of the country's total forest area. These community-based organizations are not only contributing to sequestering carbon dioxide by sustainable management of forest resources, but also playing effective roles in designing and implementing CAPA based on forest and non-forest benefits (Nepal's INDC, p. 4).
} 
invest in housing improvements to adapt to floods, heat, and typhoons, respectively (Moench et al. 2015).

\subsubsection{Autonomous Adaptation May Be Unable to Manage New Risks and 'Surprises' from Climate Change}

Although individual and institutional efforts in adapting to climate change are under way, new challenges continuously emerge as "surprises" and many of them are difficult to tackle. Crop failures and life threats caused by new pests and diseases, long droughts, flash floods, GLOF, forest fires, thunderstorms, hail, and other disasters are becoming more unpredictable, irregular, and fierce. Very little is known about the ecological, social, economic, and political conditions required to adapt to such surprises and changes (Varma and Mishra 2017). According to the communities in the eastern Himalaya in India, traditional coping strategies enabled them to withstand environmental stresses, but it is not sufficient to fully insure them from the various threats of climate change likely to occur in the near future (Barua et al. 2014).

Kusters and Wangdi (2013) argued that, as opposed to extreme events such as floods and GLOF, gradual changes such as changes in water supply can be overlooked. They reported that individual efforts by farmers in the Punakha region of Bhutan to adapt to changes in water supply were insufficient and required external support. They also argued that such gradual changes not only lead to loss of income but also impact social cohesion from increasing conflicts where water-sharing rights are being stressed.

Autonomous adaptation within and across communities varies greatly. Systematic documentation of such responses is limited, and attempts at their scientific validation are rare. Moreover, autonomous adaptation is largely a response to current climate variability rather than to future climate change impacts. Even for current climate variability, there is often a time lag in autonomous response which may be explained by structural rigidities. There is also the role of "aspirations" as a driving force that can influence people's decisions on whether to adopt autonomous adaptation measures or, say, to migrate to cities when faced with adversity.

Some autonomous adaptation practices in response to current climate variability can lead to ecosystem imbalance. Robledo et al. (2012) found that small-scale farmers in Tanzania rely heavily on forest resources for subsistence and income-generating activities. Consequently, their short-term coping practices of fuelwood cutting and selling, charcoal and craft making, and forest products hunting are not sustainable and can hasten deforestation. Such an observation is applicable to the HKH as well.

\subsubsection{Local Adaptation Knowledge Merits Greater Attention from Science and Policy}

In the HKH there are many instances of traditional institutions playing instrumental roles in managing common resources and sharing benefits accruing from it (Bawa et al. 2008; Chaudhary 2011; Ostrom 1990). For instance, the indigenous system of managing local community land and natural resources including forests, water, and biodiversity is the Dzumsa system practised by Lachungpas of northern Sikkim, Na Zong Nyo by Lepchas of Sikkim, Kipat by Rai and Limbus, and Sok shing in Bhutan (Chettri et al. 2007). Kharka pratha (managing pastures), mahavir (bee cliffs), and customary laws for governing fishing are examples of indigenous practices in parts of the Kanchenjunga Landscape (Khattri 2008). The winter grass cutting ceremony practised in the Kanchenjunga region to manage fodder supply is also a local institution evolved to manage forest resources (Brown 1994; Müller-Boker and Kollmair 2000). Pastoralists perform ubhauli (upward movement of herds) and udhauli (downward movement of herds) celebrations at certain times of the year before herds are moved from one location to another. Guthi is practised to collect and save grain in communal storage, to be used when crops fail following epidemics and endemics.

Current research on adaptation in the $\mathrm{HKH}$ largely ignores the local-level knowledge systems that are often repositories of traditional knowledge and resource management practices (Kreutzmann 2011; Manandhar et al. 2012). Traditional knowledge-based practices are clearly useful for adapting to the climate variability historically experienced by the communities. There is, however, a need for generating evidence to establish that such knowledge systems are equally relevant when it comes to dealing with the uncertainty and "surprises" likely to arise from future climate change and its impacts.

Blending tacit and scientific knowledge can play an instrumental role in generating location-specific and efficient adaptation innovations (Chhetri et al. 2012). $\mathrm{Xu}$ and Grumbine (2014) presented examples from the Asian highlands of "hybrid" forms of adaptation that combine traditional knowledge and bottom-up practices with top-down government-supported strategies, as an alternative to depending on traditional practices alone. In China's Yunnan Province, farmers have been adapting to climate-driven water stress through a combination of local knowledge (changing planting patterns), market dynamics (switching to commercial crop varieties), and government support (state-funded water storage). From Bhutan, Nepal, and Pakistan there are examples of rural communities combining expert opinion on climate change impacts with local 
knowledge, and engaging with non-governmental organizations (NGOs) for DRR and management. Xu and Grumbine (2014), however, also argued that the choice of such hybrid forms does not seem to follow detailed foresight and adaptive planning, and that they are usually taken up randomly when conditions of climatic stress prevail.

\subsection{State-Led Planned Adaptation in the HKH}

The HKH countries currently have various adaptation responses at national and subnational levels through policies, programmes, and projects (Table 13.3). The majority of the national adaptation projects and programmes relate to watershed management, climate-resilient agriculture, improved access to information for decision making, and DRR.

\subsubsection{Commonalities Among Policy Responses of National Governments}

In terms of the policy goal or vision there is a common emphasis across $\mathrm{HKH}$ countries on building resilience at the community level and in core economic sectors. Resilience in the agriculture sector is the first priority of Myanmar's NAPA (2012). The 2011 Climate Change Policy of the Government of Nepal aims to build resilience of local communities by enhancing their capacities for efficient natural resource management and use of climate-friendly technologies (MoE 2011). The 2012 National Climate Change Policy of the Government of Pakistan gives particular attention to the needs of economically and socially vulnerable sectors of the economy for the success of climate-resilient development in the country (MoCC 2012).

China's 2013 National Strategy for Climate Change Adaptation aims to significantly enhance the country's capacity to respond to extreme climatic events and thereby build resilience in key sectors ranging from human health to infrastructure (ADB 2015). The whole country is divided into three types of adaptation regions - urbanized, agricultural, and ecological — to undertake specific adaptation tasks. For example, in the Qinghai-Tibet Plateau, one of the five major ecological regions, the tasks include assessment of the plateau's grassland-carrying capacity, grassland enclosure and recovery, glacier monitoring, wetland management, and development of highland valley agriculture.

The immediate to short-term adaptation interventions identified in the national climate policies seem to revolve around strategic knowledge generation accompanied by public awareness and institutional capacity building. For instance, Bhutan's adaptation interventions through the
NAPA 1 and NAPA 2 projects focus on reducing the physical risk of climate-induced disasters such as GLOF, landslides, flash floods, and forest fires, and strengthening capacity at national and local levels in early-warning systems and disaster risk management. Livelihoods and agriculture at the district and community levels have also been the focus of recent interventions. The national strategy and adaptation priorities for Bangladesh focus on reducing the risk of climate-induced hazards and extreme events through improved early-warning systems for tropical cyclones, floods, flash floods, and droughts. The priorities also include sector-specific climate-resilient interventions and capacity building at individual and institutional levels to plan and implement adaptation programmes and projects in the country.

Governments in the $\mathrm{HKH}$ have started to integrate and mainstream climate change in their development planning and budgeting systems (Ahmed et al. 2018). The establishment of a trust fund in Bangladesh and climate change budget code in Nepal are some examples of these mainstreaming efforts. Afghanistan, Pakistan, Bhutan, and China have also devised policy measures to integrate climate change within ongoing sectoral policies and strategies. Bangladesh's adaptation priorities are well integrated into development plans, and development priorities are discussed in the context of climate change adaptation (Saito 2012). Bhutan has been integrating environment and climate change into development planning, with climate change identified as one of the national key result areas of the 11th Five-Year Development Plan (2013-18) and in planning at sectoral and decentralized levels through the Poverty Environment Initiative. As indicated in the country's NDC, adaptation will be a focus in the next development plan, and the integration of adaptation planning into the development process will be pursued through the NAP process.

There are indications of policy convergence in $\mathrm{HKH}$ countries although implementation continues to be sectoral. The majority of the national commitments in the NDCs of Bhutan, India, Pakistan, Nepal, Bangladesh, and Myanmar have included sectoral policy targets, and many of the sectoral policies in these countries - such as agriculture, forestry, water resources, and energy - are strongly interlinked with climate change policies and programmes. Thus, for instance, the National Integrated Water Resources Management Plan 2016 for Bhutan integrates climate change measures into actions and strategies. The main integration component of the Plan is the Bhutan Water Security Index (BWSI). The BWSI will be the basis for measuring water security and for coordinating planning and performance monitoring of water resource management across various agencies. Disaster and Climate Resilience is one of the five key dimensions used to calculate the BWSI. 
Table 13.3 Status of government response to adaptation needs in HKH countries

\begin{tabular}{l|l}
\hline Country & Key adaptation response at policy level and implementation highlights \\
\hline Afghanistan & $\begin{array}{l}\text { Policy response: National CCSAP (being finalized); NAPA for Climate Change (NAPA 2009) and National Capacity Needs } \\
\text { Self-Assessment for Global Environmental Management in 2009. Integration of climate change in policies and plans (e.g., National } \\
\text { Environmental Action Plan) } \\
\text { Implementation highlights: Support provided by international community and multilateral agencies; GEF has provided support } \\
\text { through enabling activities, mid-size projects, and full-size climate change adaptation projects funded by the LDC Fund }\end{array}$ \\
\hline Bangladesh & $\begin{array}{l}\text { Policy response: Bangladesh CCSAP in 2009, BCCTF and Bangladesh Climate Change Resilience Fund; NAPA in 2005 (revised } \\
\text { in 2009); adopted a policy decision by an interministerial body to mainstream climate change in project design of any project under } \\
\text { ADP, to be guided and coordinated by the Ministry of Planning } \\
\text { Implementation highlights: Adaptation projects targeting different sectors and vulnerable geographic areas (e.g., coastal } \\
\text { afforestation, pilot programme on climate resilience). Over the last three decades, the GOB has invested over USD10 billion (at } \\
\text { constant } 2007 \text { prices) to make the country more climate resilient and less vulnerable to natural disasters. In recent times GOB has } \\
\text { been investing about } 23 \% \text { of its ADP in projects related to climate variability and change. By June 2015 BCCTF had funded over } \\
\text { 236 projects of which } 41 \text { had been implemented }\end{array}$
\end{tabular}

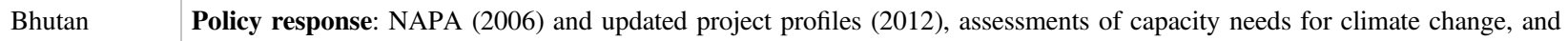
technology needs assessment for adaptation (2013), initiation of national Climate Change Policy in 2016. Framework to mainstreaming environment, climate change and poverty concerns into Five Year Plan (2013-18), the Integrated Water Resources Management Plan 2016, the National Action Program to Combat Land Degradation 2014, and the National Biodiversity Strategy and Action Plan 2014

Implementation highlights: Urgent adaptation priority projects such as GLOF risk reduction; reducing risk of landslides and flash floods in key economic and industrial zones; strengthening national capacity for early warning for GLOF, flash floods, and weather forecasting; pilot projects in agriculture, forestry, and capacity building of local and community disaster management groups

China $\quad$ Policy response: National Program on Climate Change, 2014-15; Action Plan for Energy Conservation, Emission Reduction and Low-Carbon Development; National Plan on Climate Change (2014-20); National Strategy for Climate Adaptation, Science and Technology Actions on Climate Change

Implementation highlights: Climate adaptation plans and activities in key sectors such as agriculture, water resources, terrestrial ecosystems, coastal zone and regions, and human health

India $\quad$ Policy response: NAPCC 2008 under which there are 10 National Missions; seven missions focus on adaptation in sectors like agriculture, water, Himalayan ecosystems, forestry, health, coastal areas, and knowledge management. State Action Plans on Climate Change prepared to mainstream climate change concerns at subnational level, National Adaptation Fund for Climate Change (NAFCC) set up in 2015, Indian Network for Climate Change Assessment (INCCA) set up in 2010

Implementation highlights: India's expenditure on programmes with critical adaptation components increased from $1.45 \%$ of GDP in 2000-01 to $2.82 \%$ in 2009-10. Expenditure on human capabilities and livelihoods (poverty alleviation, health improvement and disease control, and risk management) constitutes more than $80 \%$ of total expenditure on adaptation in India

Myanmar $\quad$ Policy response: Draft Myanmar CCSAP 2016, Myanmar Action Plan on Disaster Risk Reduction (MAPDRR 2012), NAPA submitted to UNFCCC in 2012

Implementation highlights: Myanmar Climate Change Alliance established in 2013, ongoing major projects funded by the Adaptation Fund and GEF (e.g., "Building Resilience and Adaptation to Climate Extremes and Disasters" (BRACED) Myanmar Programme launched in March 2015; project on "Addressing Climate Change Risks on Water Resources and Food Security in the Dry Zone of Myanmar"; and project on rehabilitation and restoration of degraded land and reserved forest through community participation)

Nepal Policy response: Launch of NAP formulation process in 2015, Climate Change Budget Code 2012, Climate Change Policy 2011, National Framework on LAPA 2011, NAPA 2010

Implementation highlights: Nepal Climate Change Support Programme, Community-based Flood Risk and GLOF risk reduction programme, Ecosystem-based Adaptation Programme, Hariyo Ban Project (climate adaptation component), and Multi-stakeholder Forestry Programme (adaptation co-benefits) under various stages of implementation. The Pilot Program for Climate Resilience (PPCR) is ongoing, comprising: (i) Building Climate Resilience of Watersheds in Mountain Eco Regions; (ii) Building Resilience to Climate Related Hazards; (iii) Mainstreaming Climate Change Risk Management in Development; and (iv) Building Climate Resilient Communities through Private Sector Participation. Climate Change Knowledge Management Centre established

Pakistan $\quad$ Policy response: Pakistan Climate Change Act (2017), The 2013 Framework for Implementation of the Climate Change Policy for 2014-30, National Climate Change Policy and National Disaster Risk Reduction Policy (2012), 18th Amendment to the Constitution on devolution of responsibilities for climate action to subnational level

Implementation highlights: State implementing projects on disaster risk management and climate resilience practices in agriculture. Also efforts by Government of Pakistan to win two Green Climate Fund projects focusing on mountain communities and GLOF. Specific budgetary allocations at national and subnational levels for execution of the 2013 Framework illustrate efforts towards mainstreaming of climate actions. Efforts by the Lahore High Court to oversee the implementation by government departments on priority areas identified under various sectors in the framework for the implementation of climate change. The Climate Change Act mandates the establishment of three important institutions: the Pakistan Climate Change Council, the Pakistan Climate Change Authority, and the Pakistan Climate Change Fund

ADP, Annual Development Plan; BCCTF, Bangladesh Climate Change Trust Fund; CCSAP, Climate Change Strategy and Action Plan; GEF, Global Environmental Facility; GLOF, glacial lakes outburst floods; GOB, Government of Bangladesh; LAPA, Local Adaptation Plans for Action; LDC, Least Developed Countries; NAPA, National Adaptation Programme of Action; NAPCC, National Action Plan on Climate Change; UNFCCC, United Nations Framework Convention on Climate Change 
The majority of the adaptation interventions in Nepal, Bhutan, and Myanmar are being guided by their respective NAPA, which by design are meant to focus on current and immediate threats, and to address these rapidly without waiting for lengthy assessment of long-term potential impacts. An anticipatory response to adaptation is reflected in the emphasis on installation of early-warning systems and structural interventions for DRR through some of the NAPA priorities/projects. Thus, for instance, in Bhutan and Nepal, the government is improving infrastructural adaptation by lowering glacier lake levels and deepening river channels, and installing early-warning systems (Adger et al. 2007; Hijioka et al. 2014; Mimura et al. 2014). Early-warning systems have been developed for extreme weather events such as flooding and wildfires (Molden et al. 2016; Shrestha et al. 2015) at many places in the HKH. In Bhutan, early-warning systems are being tested in infectious disease prevention and vector control programmes, as for malaria (Wangdi et al. 2010), and the network of hydrometeorological stations is being strengthened to increase national capacity to provide early warning for various climate-induced disasters. Sustainable land and watershed management interventions are also being emphasized for the anticipatory approach to providing adaptation benefits. ${ }^{9}$ In China, the government has attempted to reduce climate vulnerability and impact by adopting adaptation options of early planting, fixing variety growing duration, and late planting (Tao and Zhang 2010). India's Integrated Agro Meteorological Advisory Service programme has provided climate information services to farmers (Tall et al. 2014). Generally, there is a need to strengthen institutional capacity in the $\mathrm{HKH}$ countries for more and better anticipatory planning on adaptation.

Building climate resilience in urban areas is emerging as an extremely critical agenda, given the key roles of these areas for larger socioeconomic and political progress, and overall development of HKH countries. Cities are hotspots of population and infrastructure, and thus extremely vulnerable and at risk (Birkmann et al. 2010; Revi et al. 2014). The IPCC AR5 concludes with "very high confidence" that urban climate change-related risks are increasing, with widespread negative impacts on people, economies, and ecosystems. The report warns about amplified risks for people living in informal settlements, hazardous areas, and in areas lacking essential infrastructure and services (Revi et al. 2014). Such a warning is of particular relevance to the growing urban settlements in the $\mathrm{HKH}$, especially because local governments in the region lack the institutional

\footnotetext{
${ }^{9}$ Ministry of Agriculture and Forests 2014, in National Action Program to Combat land Degradation 2014 and the National Biodiversity Strategy and Action Plan 2014.
}

capacity to deal with the twin problems of climate change and providing for rapidly increasing migration into cities (and thus growth of the urban poor). There are some encouraging examples, though, and the city of Chittagong in Bangladesh provides a good example for planned adaptation by the government. Situated on the Bay of Bengal, the city is frequently prone to cyclones and high tides, and institutional mechanisms have been building the city's responsive capacity, despite being constrained by financial limitations. During periods of non-disaster the City Corporation Disaster Management Committee formulates preparedness activities such as establishing mechanisms for forecast dissemination, drills, and shelter preparation. During times of disaster they are able to recruit more members and respond quickly, thus increasing efficiency (Tanner et al. 2008).

A systematic review of national-level climate policy documents in the HKH reveals that they all aim to build the adaptive capacity of people by means of providing livelihood security in the face of climate change risks; in practice, two-thirds of a total of 21 adaptation projects reviewed in the study were found to be focused on disaster risk management and capacity building (Sud et al. 2015). While this may be an indication of policy-practice disconnect, Ford et al. (2014) are right in cautioning that there are many undocumented adaptation actions and many others possibly built into existing mainstreamed programmes to address development priorities. Some adaptation practices may provide unexpected livelihood benefits, such as the introduction of traditional flood mitigation measures in China leading to reductions in both the physical and the economic vulnerabilities of local communities (Yu et al. 2009).

Research into field-level evidence shows that government-run adaptation efforts in the South Asia region are mostly extensions of business-as-usual activities, which might be inadequate in the long run to meet adaptation needs under the post-NDC global emission regime (Ahmed et al. 2018). Exceptions, like GLOF risk mitigation projects, are rare. An enhanced and intensified adaptation response is needed in these countries, and particularly in the mountain regions, to reduce gaps between growing adaptation needs and actual adaptation delivery.

\subsubsection{HKH Countries Have High-Level Polities to Coordinate Decentralized Government Action on Climate Change}

The overall governance for climate change in Pakistan is under the Prime Minister's Committee on Climate Change, an overarching body formed in 2004. Pakistan was also one of the first countries to set up a Ministry of Climate Change, in 2012. The Pakistan Climate Change Act (17 March 2017) envisages an overarching Pakistan Climate Change Council 
headed by the Prime Minister of Pakistan, with representation of subnational governments at the Chief Ministerial level. The new law also envisages establishment of a high-powered Pakistan Climate Change Authority and Pakistan Climate Change Fund.

India's Prime Minister's Council on Climate Change and Nepal's Climate Change Council, also headed by the Prime Minister, were established in 2007 and 2009, respectively. In Bhutan the high-level National Environment Commission, which is the highest decision-making body in the government on matters related to environment and is chaired by the Prime Minister, functions as the National Climate Change Committee.

In 2007 the Chinese government set up the National Leading Group (NLG) to Address Climate Change, headed by the Chinese premier, to draw up important strategies, policies, and measures related to climate change. The National Development and Reform Commission (NDRC) under the State Council was vested with the authority to undertake the general work in respect of climate change. In 2008 a department was established in the NDRC, responsible for organizing and coordinating action on climate change all over the country. The Department of Climate Change was transferred to the Ministry of Ecology and Environment (MEE) in 2018.

Given the federal structure of government in most $\mathrm{HKH}$ countries, there is a trend towards decentralization of government action on climate change in the region. Soon after the approval of Pakistan's 2012 climate policy, a constitutional amendment (18th Amendment) delegated most of the action areas to the provincial governments. This constitutional amendment meant that the provinces had to begin to develop their own projects, allocate their own resources, and strengthen their own institutions. Responding to the challenge, Khyber Pakhtunkhwa, Punjab, and Sindh have started developing their own climate change policies and action plans.

In China, the governance system and working mechanism to address climate change features the unified leadership of the NLG, administration by the MEE and NDRC, division of work among relevant departments under the State Council, and wide participation of various localities and industries. All provinces, autonomous regions, and municipalities directly under the State Council, as well as some subprovincial or prefectural cities, have established their own institutional mechanisms to address climate change.

In India, subnational policy making has resulted in State Action Plans on Climate Change that identify adaptation interventions relevant to the local context. A number of adaptation projects in Indian Himalayan states are being funded by India's National Adaptation Fund.

The trend towards decentralized policy making on adaptation is justified on the grounds that the response to climate change impacts has to be at the local level. However, there is little understanding and research happening regarding the ideal distribution of adaptation responsibilities among various levels of government. An important aspect of decentralization on adaptation is the extent and nature of decentralized access to adaptation finance by provincial and local governments. As Table 13.4 shows, two HKH countries (India and Bangladesh) have established statutory funding mechanisms for the flow of adaptation finance to local levels of governance; in some others (Bhutan, Bangladesh, Nepal) there is access to international sources.

\subsubsection{Public Consultation and Stakeholder Engagement in Adaptation Planning and Implementation Is Very Uneven Among the HKH Countries}

Effective adaptation interventions require harnessing synergies among various government schemes along with stakeholder involvement in monitoring and evaluation of policy implementation (Sud et al. 2015). Stakeholder engagement strategies are a crucial aspect of adaptation interventions (Sherman and Ford 2014). However, public consultation and stakeholder engagement in adaptation planning and implementation is highly uneven and, more often than not, ad hoc within HKH countries. For instance, it has been pointed out that in Nepal the NAPA consultations may have missed out on opportunities to promote inclusive climate change responses, particularly to accommodate the concerns of diverse community groups in the country (Ojha et al. 2015).

There are examples showing that in the absence of collaboration among local stakeholders and national actors, many of the adaptation measures failed to deliver and instead led to maladaptive practices (Regmi and Star 2015). Lack of participation can also create mistrust and lack of ownership, leading to new forms of exclusion or reinforcing existing exclusions. Analysis of relevant literature suggests that adaptation planning that relies heavily on select institutions and actors, and powerful social structures at the local level, is likely to create new inequalities. Regmi et al. (2016) in their study of community adaptation planning in Nepal found that in the presence of elite domination of local institutional mechanisms there is no guarantee that poor and vulnerable households will benefit from adaptation interventions. There is instead a new form of dependency of the marginalized groups on the local elites for receiving benefits from the projects or programmes. Nagoda and Nightingale (2017) argue that, in Nepal, there is the risk of climate change adaptation projects reinforcing power relations that perpetuate the vulnerability context. The case studies of adaptation planning in other LDCs and developing countries also illustrate how even participatory methods can fail to genuinely empower or involve marginal communities in adaptation 
Table 13.4 Local funding mechanisms for adaptation

\begin{tabular}{|c|c|c|c|c|}
\hline Funding mechanism & Managed by & Nature of support & Purpose & Mechanism \\
\hline $\begin{array}{l}\text { National Adaptation } \\
\text { Fund for Climate } \\
\text { Change (NAFCC), India }\end{array}$ & $\begin{array}{l}\text { Ministry of } \\
\text { Environment, Forests } \\
\text { and Climate Change } \\
\text { (MoEF\&CC), } \\
\text { Government of India }\end{array}$ & Projects & $\begin{array}{l}\text { To promote subnational } \\
\text { level adaptation } \\
\text { activities and good } \\
\text { practices across the } \\
\text { country }\end{array}$ & $\begin{array}{l}\text { Grants are disbursed to } \\
\text { state agencies and civil } \\
\text { society organizations } \\
\text { based on the needs and } \\
\text { priorities identified } \\
\text { under the National and } \\
\text { State action plans }\end{array}$ \\
\hline $\begin{array}{l}\text { The Local Climate } \\
\text { Adaptive Living Facility } \\
\text { (LoCAL), International } \\
\text { (HKH countries having } \\
\text { LoCAL_-Bangladesh, } \\
\text { Bhutan, Nepal) }\end{array}$ & $\begin{array}{l}\text { United Nations Capital } \\
\text { Development Fund } \\
\text { (UNCDF) }\end{array}$ & Projects & $\begin{array}{l}\text { To integrate climate } \\
\text { change adaptation into } \\
\text { local governments' } \\
\text { planning and budgeting } \\
\text { systems, increase } \\
\text { awareness and response } \\
\text { to climate change at } \\
\text { local level, and increase } \\
\text { the amount of finance } \\
\text { available to local } \\
\text { governments for climate } \\
\text { change adaptation }\end{array}$ & $\begin{array}{l}\text { LoCAL combines } \\
\text { performance-based } \\
\text { climate resilience grants, } \\
\text { which ensure } \\
\text { programming and } \\
\text { verification of climate } \\
\text { change expenditures at } \\
\text { the local level, with } \\
\text { technical and } \\
\text { capacity-building } \\
\text { support }\end{array}$ \\
\hline $\begin{array}{l}\text { Bangladesh Climate } \\
\text { Change Trust Fund } \\
\text { (BCCTF) }\end{array}$ & $\begin{array}{l}\text { An independent trustee } \\
\text { board chaired by } \\
\text { ministry of environment } \\
\text { and forests, government } \\
\text { of Bangladesh }\end{array}$ & Projects & $\begin{array}{l}\text { To support the } \\
\text { implementation of } \\
\text { Bangladesh's Climate } \\
\text { Change Strategy and } \\
\text { Action Plan (CCSAP) }\end{array}$ & $\begin{array}{l}\text { Grants disbursed } \\
\text { through line ministries }\end{array}$ \\
\hline $\begin{array}{l}\text { Bangladesh Climate } \\
\text { Change Resilience Fund } \\
\text { (BCCRF) }\end{array}$ & $\begin{array}{l}\text { Government of } \\
\text { Bangladesh with } \\
\text { technical assistance } \\
\text { from the World Bank }\end{array}$ & $\begin{array}{l}\text { Projects and responding } \\
\text { to emergency needs }\end{array}$ & $\begin{array}{l}\text { To support the } \\
\text { implementation of } \\
\text { Bangladesh's Climate } \\
\text { Change Strategy and } \\
\text { Action Plan (CCSAP) }\end{array}$ & $\begin{array}{l}\text { Grants disbursed } \\
\text { through line ministries }\end{array}$ \\
\hline $\begin{array}{l}\text { Bangladesh Local } \\
\text { Disaster Risk Reduction } \\
\text { Fund (BLDRRF) }\end{array}$ & Technical committee & $\begin{array}{l}\text { Small and medium-size } \\
\text { projects }\end{array}$ & $\begin{array}{l}\text { To support the most } \\
\text { vulnerable communities } \\
\text { through NGOs and } \\
\text { Union Disaster } \\
\text { Management } \\
\text { Committees }\end{array}$ & $\begin{array}{l}\text { Grants disbursed based } \\
\text { on risk reduction action } \\
\text { plans }\end{array}$ \\
\hline
\end{tabular}

interventions, in both top-down and bottom-up approaches (Dodman and Mitlin 2013; Sherman and Ford 2014).

Regmi et al. (2016) suggested that local institutions could be made more accountable and responsive to vulnerable households by devolving decision-making power to these households and ensuring inclusive provisions in membership, representation, and resource allocation. Wong (2010) suggested that success in dealing with elite capture lies in the flexible use of "counter-elite" and "co-opt-elite" approaches, together with addressing the need to secure alternative livelihoods and to achieve empowerment for the poor.

The multi-stakeholder-led LAPA process in Nepal is considered to be a successful model for mobilizing local institutions and community groups in adaptation planning and recognizing their role in adaptation. This LAPA framework was developed with the participation and support of government, development partners, and civil society organizations. Adaptation investments were costed by the
Government of Nepal and integrated into annual budget plans and resource mobilization strategies (Maharjan and Maharjan 2017). At present, Nepal is implementing LAPA in 90 village development committees and seven municipalities (the lowest administrative units in the country). Similarly, about 375 local adaptation plans and nearly 2,200 Community Adaptation Plans of Action for community forests have been developed (Nepal's NDC:6). The experience of making LAPA in Nepal can be considered a replicable model of a bottom-up approach to adaptation planning for mountain communities.

Pakistan, on the other hand, has implemented LAPA at the state and local levels through the support of NGOs. An analysis of LAPA in Nepal and Pakistan concluded that Nepal's focus on official formalization of the process has come at the cost of delayed implementation, while Pakistan's devolved implementation-centric approach lacks official buy-in to nationally scale up the LAPA (Chaudhury et al. 2014). 


\subsubsection{Limited Tailored Response to Gender and Social Inclusion}

Some HKH countries have national-level climate policies that explicitly identify the most vulnerable groups (indigenous peoples, migrants, and women, for instance), but very few that seek to address their specific adaptation needs through tailored responses (see Box 13.2).

\section{Box 13.2 Country policies and treatment of marginalized people}

- Pakistan's National Climate Change Policy 2012 explicitly provides for ensuring the rights of indigenous people in the management of rangeland and pastures. It also has detailed provisions for mainstreaming gender perspectives into climate change adaptation, ensuring women's participation in decision making on climate initiatives, and using the indigenous knowledge of women in climate adaptation (MoCC 2012)

- Nepal's Climate Change Policy 2011 provides for the participation of indigenous communities and women in the implementation of climate change-related programmes, and identifies the importance of traditional knowledge in climate adaptation (MoE 2011). Gender is explicitly included as a cross-cutting theme in Nepal's NAPA, and gender-differentiated information was collected through participatory approaches during its formulation (Mainlay and Tan 2012). In the ongoing NAP process, gender and social inclusion is a cross-cutting theme

- Although India's NAPCC does not explicitly mention indigenous peoples, the National Mission for Sustaining the Himalayan Ecosystem under NAPCC addresses the importance of traditional knowledge and community-based natural resource management in the Indian Himalaya (NAPCC 2008). India's NAPCC recognizes the differential impacts of climate change with respect to gender, but incorporates only a few gender-specific measures in any of its national missions (Parikh et al. 2012)

- Bangladesh's Climate Change Strategy and Action Plan (CCSAP) identifies women as a special category of vulnerable group and has special programmes for incorporating gender consideration into climate change management. Within the $\mathrm{HKH}$ countries, it is the only climate change policy document that addresses the issue of climate-led forced displacement. The document has provisions to build the capacity for education and training of environmentally displaced people to ease and facilitate their migration and integration into new societies (MoEF 2009)

- Myanmar's CCSAP (2016) specifies implementation plans for poor and landless households in vulnerable areas of dry zone, delta, mountain, and coastal areas in terms of initiating eco-friendly crops, bioenergy schemes, and livelihood diversification activities (MoNERC 2016)

Studies from Nepal and India have reported local cultural and institutional factors that act as barriers to adaptation, particularly for women (Ahmed and Fajber 2009; Jones and Boyd 2011). Because of women's limited ownership of land, they are still largely excluded from training, extension services, irrigation management, and development schemes intended for farmers (Gioli et al. 2014). Despite the policy provisions, realizing adaptation goals for women and socially marginalized groups in the $\mathrm{HKH}$ is likely to be very challenging unless there is urgent and more targeted action on the ground to strengthen and improve their access to and control over productive assets, access to formal and non-formal education, mobility, and opportunities to generate income.

\subsubsection{Implementing Adaptation Programmes Is Challenged by Institutional Inertia and Inadequate Institutional Capacity}

At both national and subnational levels, HKH countries have weak institutional capacity to deal in an effective and timely manner with climate change impacts. Major gaps exist between policy targets and actual implementation of adaptation programmes.

Most institutional capacity needs are related to access to information, knowledge, and resources. National governments have recognized the seriousness of climate change and have submitted NAPA, but significant scientific knowledge and data gaps remain (Davis and Li 2013). Li et al.'s (2012) assessment of adaptation knowledge needs for China concluded that there is need for a knowledge support system to generate, communicate, and manage climate change knowledge and information in support of policy- and decision-making processes at all levels. In the case of India there are financial, technological, and knowledge gaps in adaptation, as well as capacity building and institutional needs (Garg et al. 2015). 
The most pervasive of barriers relate to poor coordination within and between organizations responsible for planning and implementing adaptation actions, and a lack of (or irrelevant knowledge/information on) climate change, as well as ineffectual communication between stakeholders involved in adaptation actions (Spires et al. 2014). In Bangladesh, the limited access of local governments to resources has been cited as a barrier to local adaptation (Christensen et al. 2012). Local planners can find it difficult to negotiate the complexity of adaptation without adequate access to guiding information on vulnerabilities and potential impacts. Local institutions are affected by lack of coordination with state and national policies and priorities, as well as by absent cross-cutting institutional coordination that is weakening environmental governance processes in the region (Tiwari and Joshi 2015).

A context-independent "one-size-fits-all" approach to adaptation interventions, and poor implementation, has the potential to result in failure and even maladaptation. Classifying maladaptation is complex, as the effects of adaptation interventions may be spread over time and geography, and across sectors and generations. A few examples that may illustrate potentially maladaptive impacts of adaptation strategies in the HKH are:

a. In the Humla region of Nepal, adaptation strategies were focused on planting drought-resistant crop varieties, which did contribute to reduced climate risk at household and community levels. However, this also led to the reinforcement of gendered roles in agricultural work and resulted in increased pressure for girls to be removed from schooling. A more gender-sensitive response to climate change could have contributed to overall welfare (Onta and Resurreccion 2011).

b. In India and Pakistan, electricity subsidies for pumping groundwater are potentially maladaptive as it can over time lead to aquifer depletion in the absence of strong institutions governing access and water abstraction (Jones et al. 2015).

c. Excessive use of pesticides is prevalent in China and, as a consequence, food production has had a negative impact on health, costing around USD1.4 billion per year. It has also adversely affected farm and off-farm biodiversity (Norse et al. 2001 cited in Rasul and Sharma 2016).

\subsection{Adaptation Initiatives by Non-state Actors Shaping Practice in the HKH}

Non-governmental actors working on climate change adaptation comprise a wide range of stakeholders including international and national NGOs, civil society organizations, community-based organizations, private business, and media. The initiatives by non-governmental actors are of paramount importance, because they are expected to complement, build synergy, and leverage resources with government programmes. Presently there is great diversity among such initiatives in the HKH.

\subsubsection{Multiple Actors and Approaches, but Little Synergy}

In many parts of the HKH it is common that, although a number of NGOs may be working on similar adaptation-related issues, more often than not there is very little functional collaboration, coordination, and communication among the actors. This results in isolation, redundancy, and duplication of interventions, and inefficient resource utilization. It has been observed that NGOs follow frameworks and approaches to adaptation that are often similar with respect to goals, tools used, envisioned actors and stakeholders, and design elements. For instance, climate-smart agriculture (CSA) is being promoted by more than a dozen international and national NGOs in Nepal to adapt to climate-led challenges in agriculture, but each tends to adopt or modify their home-grown practices, and little effort is made to cross-fertilize the ideas (Bhatta et al. 2016).

The frequently used frameworks and approaches in the HKH include sustainable livelihoods framework, ${ }^{10}$ community-based adaptation ${ }^{11}$ (CBA), and ecosystem-based adaptation $^{12}$ (EBA). CSA, ${ }^{13}$ climate-smart villages, and climate-compatible development adaptation are also concepts that have come to be used in recent years. Adaptation interventions based on these approaches are generally motivated by the argument for "no or low regrets" actions, which are good options regardless of the need to adapt to climate change. Thus, for example, CSA makes sense with

\footnotetext{
${ }^{10}$ This framework considers financial, social, physical, human, and natural capital (Brooks and Adger 2005).

${ }^{11} \mathrm{CARE}$ uses climate-resilient livelihoods, disaster risk reduction, capacity building, and addressing underlying causes of vulnerability as the core themes of its community-based adaptation framework (http:// careclimatechange.org/wp-content/uploads/2015/04/CBA_Framework. pdf).

${ }^{12}$ Payment for ecosystem services is widely piloted in the HKH as an EBA approach. Park and Alam (2015) give the example of EBA focused on agro-forest-based adaptation practices to build ecosystem and community resilience in Nepal.

${ }^{13}$ The term CSA was coined by the Food and Agriculture Organization (FAO) at the Hague Conference on Agriculture, Food Security, and Climate Change in 2010. It is defined as agriculture that "sustainably increases productivity, enhances resilience, reduces/removes greenhouse gas emissions, and enhances achievement of national food security and development goals" (FAO 2010). Various international and national NGOs have been implementing the CSA concept in the HKH (ICIMOD 2015; LI-BIRD 2015).
} 
or without climate change: building more productive and resilient agriculture systems will also increase resilience to climate change.

Bangladesh is possibly the global leader in pioneering people-centric, small-scale adaptation initiatives, which are generally planned and executed by non-state actors. The pioneering role of an early initiative called Reducing Vulnerability to Climate Change (RVCC), implemented by CARE Bangladesh with numerous partner organizations including local government and non-governmental partners between 2002 and 2005, laid the foundation towards designing and delivering concepts such as CBA and EBA (Ahmed 2010). Although the pilot-scale project was implemented in the southwestern region of Bangladesh, the concepts have been further examined, extended, and tested repeatedly by both non-state and government actors across Bangladesh, and gradually across more than 70 countries. ${ }^{14}$

As a result of the early successes of CBA methodology and efforts, the Government of Bangladesh allocated about $10 \%$ of its climate financing to engage non-state actors towards further refinement of CBA activities. Such activities encompass micro-level agricultural adjustments to ensure continuation of crop production in climate-affected areas by adopting hazard-tolerant crops, adjusting crop calendars based on early signs of climate trends, replicating advanced agronomic practices, and enhancing farmers' skills to switch to livelihood practices that are not directly affected by climate variability or change. Moreover, CBA activities embrace small-scale water management practices, DRR practices, and creation of protection measures either to reduce vulnerability by reducing exposure to known climate-induced hazard(s) or to reduce sensitivity to such known hazards (Ahmed 2010). Although such measures are gaining rapid popularity among users (because of their relative simplicity to replicate at low cost), as well as among non-state actors, it is argued that they might not be adequate in ensuring resilience of affected communities to such a considerable extent that the remaining vulnerability appears only negligible (Ahmed et al. 2018).

In China, numerous innovative and indigenous ecosystem-based approaches to adaptation have been implemented all over the country. In this regard, the Chinese Ecosystem Research Network (CERN) established by the Chinese Academy of Sciences (CAS) in 1988 provides substantial best practices that are collected and documented during its long-term investigation and management of typical ecosystems in China. Demonstration efforts (Table 13.5) have been made to improve low-yield croplands on the North

\footnotetext{
${ }^{14}$ Since 2007 the London-based International Institute for Development Studies and the Dhaka-based Bangladesh Centre for Advanced Studies have been organizing annual CBA conferences and helping global extension of good lessons learnt.
}

Table 13.5 Major technologies and demonstration models for ecosystem-based adaptation by the Chinese Ecosystem Research Network

\begin{tabular}{|c|c|}
\hline Demonstration model & Key issues of the ecoregion \\
\hline $\begin{array}{l}\text { Qianyanzhou Model (forest } \\
\text { ecosystem) }\end{array}$ & $\begin{array}{l}\text { Comprehensive, controlled and } \\
\text { agriculturally sustainable } \\
\text { development in hilly areas, } \\
\text { south China }\end{array}$ \\
\hline $\begin{array}{l}\text { Technology for saline-alkali } \\
\text { soil treatment (cropland } \\
\text { ecosystem) }\end{array}$ & $\begin{array}{l}\text { Comprehensive treatment of } \\
\text { middle- and low-yield fields on } \\
\text { the Huanghuaihai Plain, north } \\
\text { China }\end{array}$ \\
\hline $\begin{array}{l}\text { Zhifanggou Model (cropland } \\
\text { ecosystem) }\end{array}$ & $\begin{array}{l}\text { Water and soil loss and } \\
\text { ecosystem restoration on the } \\
\text { Loess Plateau }\end{array}$ \\
\hline $\begin{array}{l}\text { "1/10 Functional Replacement" } \\
\text { Model for Degraded Grassland } \\
\text { Restoration (grassland } \\
\text { ecosystem) }\end{array}$ & $\begin{array}{l}\text { Adaptive management and } \\
\text { sustainable development of the } \\
\text { Xilingol grassland, north China }\end{array}$ \\
\hline $\begin{array}{l}\text { Shapotou Model for } \\
\text { Desertification Combating } \\
\text { (desert ecosystem) }\end{array}$ & $\begin{array}{l}\text { Construction of sand-fixing } \\
\text { vegetation protection system in } \\
\text { arid sand area, northwest China }\end{array}$ \\
\hline $\begin{array}{l}\text { "Three Ring" } \\
\text { Ecology-Production Paradigm } \\
\text { of Ordos Plateau (desert } \\
\text { ecosystem) }\end{array}$ & $\begin{array}{l}\text { Sustainable management of } \\
\text { desertified land on the Ordos } \\
\text { Plateau, north China }\end{array}$ \\
\hline $\begin{array}{l}\text { Technology for Water } \\
\text { Remediation (lake ecosystem) }\end{array}$ & $\begin{array}{l}\text { Treatment of eutrophication and } \\
\text { algal blooms of freshwater } \\
\text { lakes, Yangtze River Delta }\end{array}$ \\
\hline $\begin{array}{l}\text { Model of fenced grassland and } \\
\text { artificial grassland (grassland } \\
\text { ecosystem) }\end{array}$ & $\begin{array}{l}\text { Wise use of natural grassland } \\
\text { and seasonal optimization of } \\
\text { livestock structures on the } \\
\text { Qinghai-Tibetan Plateau }\end{array}$ \\
\hline
\end{tabular}

Source Chinese Ecosystem Research Network Annual Report 2012 (in Chinese)

China Plain, soil and water conservation on the Loess Plateau, revegetation of hilly regions in southern China, rehabilitation of eutrophic lakes, protection and recovery of natural vegetation in ecologically fragile areas such as desertified areas, karst systems, agro-pasture ecotones, and permafrost.

\subsubsection{Scaling up and Sustainability: Challenges Common to Projects Implemented by NGOs}

Projects implemented by NGOs are too spread out, small scale, short term, and often embarked upon as piloting, testing, and experimentation, with little chance of being scaled up after project funding ends. The support is not adequate to reach out to a large number of households and make a real lasting impact on a wide scale. The technologies and practices to be promoted are poorly scaled up, partly because the projects are rarely integrated into government programmes. On the other hand, scalability via traditional 
government or civil society implementation is limited because of institutional inertia and capacity constraints. A recent assessment of adaptation projects in the rainfed agriculture sector in India highlighted four fundamental enabling factors for scalability: resources, partnerships, knowledge management, and understanding of the local context (Appadurai et al. 2015).

There are some success stories of NGO activities being taken up by government and made part of the adaptation policy framework. For instance, the Government of Nepal is scaling up a home garden approach in 20 districts to promote on-farm diversity to contribute to food and nutrition and improve resilience (diversity for adversity) of smallholder farmers with the technical support of an NGO. Similarly, the riverbed farming practice pioneered in Nepal by a local NGO has recently been mainstreamed into national policy, with the Ministry of Local Development producing riverbed farming guidelines in collaboration with the Riverbed Farming Alliance. ${ }^{15}$ Gurung et al. (2014) ${ }^{16}$ explained how leasehold riverbed vegetable farming is helping landless and land-poor households to form groups and gain economically by using the dry, sandy beds left after the flooded rivers recede in the terai plains of Nepal. Among other factors, extreme weather events such as flash floods are linked to the increasing area of sandy riverbeds, and there is potentially an adaptation opportunity in training the landless poor and marginal farmers to take advantage of this underexploited resource (seasonally dry riverbeds) for income diversification purposes.

In Nepal a novel multilevel institutional partnership that includes collaboration with farmers and NGOs has been instrumental in the innovation of location-specific technologies, thereby facilitating the adoption of technologies in a more efficient manner. This alliance has not only improved knowledge networking among institutions, scientists, and farmers, but also led to more efficient adoption of technologies by farmers. This is evident from NGO work on CSA and participatory plant breeding work (Bhatta et al. 2016; Gyawali et al. 2006).

NGOs are good at securing community participation, but they sometimes develop programmes and suggest policies without adequate public consultation and validation. In many cases proposals seem to be developed in accordance with donor requirements and lack on-the-ground reality. There is also research showing that NGO-promoted participation can be limited to those who are elite, educated, male, and higher caste, often leading to marginalization of the poor, women, and vulnerable households (Regmi et al. 2016).

\footnotetext{
${ }^{15} \mathrm{http}: / / \mathrm{www}$. riverbedfarmingalliance.org.np/news-and-events.html

${ }^{16} \mathrm{http} / / /$ www.satnetasia.org/sites/default/files/SATNET-FS04-Riverbed $\% 20$ Farming.pdf
}

The media has often been playing a supporting role, especially in promoting good CBA practices and highlighting the adaptation needs of certain vulnerable groups and locations in the HKH. It has also played a significant role in highlighting the need for participatory governance in climate financing in a few HKH countries such as Bangladesh and Nepal (Ahmed et al. 2018). The inspiring reports of electronic and printed media in Bangladesh have encouraged many non-state actors to emulate CBA activities in different ecosystems, while the media in Nepal has been involved in LAPA processes.

\subsection{Financing Adaptation in the $\mathrm{HKH}$}

Finance is the biggest challenge to achieving an adequate adaptation response to climate change impacts in the HKH. To date, the quantum of funds accessed for adaptation purposes from international sources by HKH countries has been grossly inadequate when compared to estimates of what is required for the region.

\subsubsection{HKH-Specific Estimates of Funding Need and Availability for Climate Change Adaptation Are Absent}

Estimating the future costs of adaptation responses to climate change impacts can be highly speculative and subject to many unrealistic assumptions, especially when many of the losses that future climate change may bring are likely to be non-quantifiable. However, it is important to put some numbers to potential adaptation costs as a way to raise urgency in addressing financial needs.

A comprehensive assessment of climate change adaptation finance need and availability is lacking for the $\mathrm{HKH}-$ for both the region as a single assessment unit and for any specific geographical area or sector in each country that falls within the HKH. ${ }^{17}$ Therefore we have no knowledge of how

\footnotetext{
${ }^{17}$ The closest financial estimate is found in the 2014 ADB report, "Assessing the Costs of Climate Change and Adaptation in South Asia" (https://www.adb.org/publications/assessing-costs-climate-change-andadaptation-south-asia). According to the report: "To avoid the damage and economic losses from climate change under the BAU scenario, the region needs to provide an average adaptation expenditure of $0.48 \%$ of GDP per annum (USD 40 billion) by 2050 and $0.86 \%$ of GDP per annum (USD 73 billion) by 2100. Obviously, regional adaptation costs under the $\mathrm{C}-\mathrm{C}$ scenario are much lower than the BAU scenario as it only requires an average of $0.36 \%$ of GDP per annum (USD 31 billion) by 2050 and $0.48 \%$ of GDP per annum (USD41 billion) by 2100 . The study took into account investment in building adaptive capacity in anticipation of future climate change as well as climate proofing measures in key sectors toward climate-resilient development" (Ahmed and Suphachalasai 2014).
} 
much finance is available, how much of the available funds has been allocated to mountain regions or spent on addressing mountain-specific issues, the basis of allocation of funds, the scale of mobilization of private sector finance, and so on.

Our assessment, presented below, has applied several assumptions while translating global and country-level assessments for the HKH.

The Fifth Assessment Report by the IPCC (Chambwera et al. 2014) reports global estimates of the costs of adaptation in developing countries ranging between USD70 billion and USD100 billion per year in the period between 2010 and $2050 .{ }^{18}$ The aggregated GDP of all developing countries (low income, lower middle income, and upper middle income) comes to USD26.53 trillion (WB 2016). Considering the aggregated GDP along with the estimated cost of adaptation for developing countries, one may argue that the cost of adaptation against each million of GDP would require about USD80,000-110,000 per year by 2030 and would increase to about USD130,000-190,000 by 2050. Considering the number of people living in the HKH and their per capita income by country, and applying a similar argument, one may argue that the region would require USD3.2 billion to USD4.6 billion per year by 2030 , which would increase to USD5.5 billion to USD7.8 billion per year by 2050 .

It is highly unlikely that international finance will be ever sufficient to address the adaptation needs of HKH countries. Mobilizing funds from domestic sources is imperative, and some countries in the region are taking steps in this regard. For example, Bangladesh has taken the lead in the region by establishing a climate change trust fund, and has already mobilized USD600 million, of which about USD400 million is from internal government resources and about USD200 million is from development partners. The Bhutan Trust Fund for Environmental Conservation also supports small-scale activities (up to USD300,000 each) in Bhutan to address impacts of climate change on ecosystems and species, as well as to support communities in accessing climate change funds from other sources.

The Government of India (GOI) has estimated that it would require about USD230 million over 5 years (201217) to support the NMSHE, and key achievements to date include establishing six new centres relevant to climate change in existing institutions in Himalayan states, creating an observational network to monitor the health of the Himalayan ecosystem, and instituting several

\footnotetext{
${ }^{18}$ According to UNEP (UNEP 2016) the costs would be much higherpossibly reaching USD300 billion per year by 2030 and USD500 billion per year by 2050 .
}

capacity-building and training programmes. Under the NAFCC established in 2015, more than one-third of the total projects sanctioned (amounting to about USD68 million) have gone to the Indian Himalayan region ${ }^{19}$ for projects such as climate resilient sustainable agriculture in rain-fed farming areas in Jammu and Kashmir, climate smart agricultural solutions in Himachal Pradesh, ecosystem management in Assam, sustainable agricultural development in Mizoram, and rejuvenation and climate proofing of springshed in Meghalaya (Gupta et al. 2018).

In addition to mobilizing domestic sources of funding, HKH countries had accessed about USD600 million from different international sources of climate finance (Climate Fund Update, ${ }^{20}$ September 2016). Countries in the HKH, except for Bangladesh, are yet to access climate change adaptation funding from the Green Climate Fund, which has allocated $50 \%$ of the fund for adaptation. The Government of China has established the USD3.1 billion South-South Cooperation Fund as an independent contribution to global climate finance, particularly for building the capacity of developing countries in adapting to climate change.

Reliable estimates of public expenditure on adaptation are essential for monitoring and evaluation of interventions by governments. Attempts to mainstream climate change financing within the national development process are still evolving. Three of the HKH countries-Bangladesh, Nepal and Pakistan - have conducted Climate Public Expenditure and Institutional Reviews (CPEIR) that provide useful estimates of the country's climate-related expenditure. ${ }^{21}$ Pakistan has gone a step ahead to replace CPEIR with an official Climate Expenditure Coding and Tracking System that will help in tracking climate change expenditures on an ongoing basis.

To reemphasize, many of the losses posed by climate change to the HKH countries are not quantifiable; even then it is important to better understand losses to culture, territory, or religious sites due to climate change impacts and to find proxy quantifiers for an eventual valuation. Climate change risks to intangible issues such as values, faith, or tradition should not be underestimated because of the difficulty of attributing a monetary value.

\footnotetext{
${ }^{19}$ This region includes 10 hill States i.e. Jammu \& Kashmir, Himachal Pradesh, Uttarakhand, Sikkim, Arunachal Pradesh, Nagaland, Manipur, Mizoram, Tripura, Meghalaya, and two partial hill States namely, Assam and West Bengal.

${ }^{20} \mathrm{https}: / /$ climatefundsupdate.org/.

${ }^{21} \mathrm{http}: / /$ www.pk.undp.org/content/dam/pakistan/docs/Environment\% 20\&\%20Climate\%20Change/UNDP\%20Climate\%20Report\%20V10. pdf.
} 


\subsubsection{Business Potential in Adaptation Is High, but Investment Is Limited}

Most businesses, while increasingly becoming engaged in mitigation of greenhouse gases, are yet to take a proactive approach to adaptation in the HKH. Few have even assessed the likely effects of climate change on their value chains and operations, although it is understood that adaptation to climate change can add significantly to a company's budget or project cost. ${ }^{22}$ The Task Force for Climate Related Financial Disclosures, however, is leading in raising awareness of the risks posed by climate change to investors and, by default, to many large companies with supply chains in the $\mathrm{HKH}$ (TCFD 2017).

That business can be a key stakeholder in adaptation policy and practice in the HKH region is demonstrated by the active participation of the Association of Bhutanese Industries and the Bhutan Chamber of Commerce and Industry in the formulation of the country's NAPA. As a result of their inputs, key industrial areas and investments in the Pasakha area in the foothills of the Bhutan Himalaya were identified and prioritized as being at risk from increasing intensity of rainfall, flash floods, and landslides (ADB 2014). The Punatsangchu Hydro Projects I and II in Bhutan are key stakeholders in the GLOF risk reduction project in the Punatsangchu Valley and have made direct contributions to the installation of early-warning systems (UNDP 2012).

Often the focus falls on the role of the private financial sector in providing risk management options, including insurance and financing for large projects (Khattri et al. 2010). However, there are major sectors of climate financing in India - such as renewable energy, energy efficiency, transport sector improvement, clean-tech, and waste management - which are either from international financing companies or from social-environmental safeguard budgets (GIZ 2015). In Bangladesh the private sector is more engaged in agriculture and climate change adaptation (IFC 2010). Case studies show that the role of the private sector can be instrumental during the period of disaster risk and rehabilitation work. It was effective during the case of post-tsunami rehabilitation work in India and other parts of Asia (Chatterjee and Shaw 2015).

\footnotetext{
${ }^{22}$ For example, the International Finance Corporation (IFC) did a risk assessment for the Khimti I Hydropower Project in Dolakha District in Nepal using scenarios of future climate change impacts including variable and uncertain streamflow in the dry season and the risks of extreme events like flash floods, landslides, and GLOF. Incorporating the increased likelihood of floods and GLOF into dam design leads to increased project cost (Communication from PCD, DHPS, MoEA cited in ADB 2014).

${ }^{23} \mathrm{https}$ ///www.gov.uk/government/uploads/system/uploads/ attachment_data/file/305412/stimulating-private-sector-engagementclimate-disaster-resilience.pdf.
}

An assessment ${ }^{23}$ carried out in Pakistan, on public finance support to stimulate private sector investment in building disaster resilience and climate change adaptation, identified the public finance interventions required to support two sectors: agriculture and construction. The study established the absence of private sector involvement in disaster and climate risk management planning frameworks, as well as in specific initiatives within key economic sectors, or at provincial or local levels.

Mobilizing investment that results in win-win outcomes and building public goods seems to be the way forward for getting business engaged in adaptation. Some other areas, such as agribusiness value chains, tourism, insurance, and climate services-in which we see the potential of business-led adaptation in the HKH-are discussed below, with examples:

- As part of the Pilot Programme for Climate Resilience in Nepal executed by the International Financial Corporation, "agribusiness companies (such as processors of rice, maize, and sugarcane) have committed to provide training to farmers to reduce crop losses and increase productivity, with the long-term aim of sustained private sector involvement and transformational change" (ADB 2014)

- Private companies are experimenting with a range of business models for ICT-based climate and market services, either to open new markets or to safeguard their supply chains. One such mobile-based initiative ${ }^{24}$ presently serves thousands of farmers in Uttarakhand State in India. Scaling up of such services in the HKH is technically feasible, as much of the forecasting can be based on (private or public European) weather satellites. Of course, to make such products financially sustainable in the $\mathrm{HKH}$, private sector providers will need to address issues of mobile connectivity, low literacy, and handholding support (customization, interactivity, responsiveness, call centres, field extension agents) for farmers.

- For insurance companies, weather index-based crop insurance is potentially a big market opportunity. Recently the Indian state of Himachal Pradesh opened weather-indexed insurance for ginger, potato, tomato, and pea crops, while a private insurer has implemented a pilot scheme in Uttarakhand and Assam States. There is a pilot-scale effort in Bangladesh towards insuring livelihoods against floods. ${ }^{25}$ In Nepal, it is reported that the Insurance Board is making preliminary regulatory changes to introduce rainfall and hailstorm insurance for apple

\footnotetext{
${ }^{24}$ http://www.icimod.org/?q=23463.

${ }^{25} \mathrm{http}$ ://oxfamblogs.org/bangladesh/wp-content/uploads/2013/08/ Product-Brochure1.pdf.
} 
farming on a pilot basis. ${ }^{26}$ Scaling up such pilot schemes remains a challenge and requires investment in a dense network of weather stations and regulatory changes. As climate risks increase under a climate change scenario, such schemes will further need to be backed by a combination of global reinsurance and public climate finance.

- Pakistan's National Disaster Management Authority is working on a disaster risk insurance fund targeting vulnerable populations for protection against climate hazards. ${ }^{27}$ In addition to public sector insurance bodies such as National Insurance Corporation Limited and Pakistan Reinsurance Corporation Limited, private sector insurance organizations have also been engaged through the Insurance Association of Pakistan. One of the key fund design recommendations coming out of this project is for a public-private partnership model. Engagement of the private sector in such an initiative is important to fulfil the capital requirements for setting up the fund and ensuring long-term financial sustainability.

\subsubsection{Opportunity to Build Adaptive Capacity from Labour Migration and Migrant Remittances}

Human mobility for livelihood purpose is a significant socioeconomic phenomenon in the HKH. The mountainous region generally has higher labour out-migration than in-migration. Whether internal or international, migrant remittances are increasingly becoming an important source of income for households in the HKH (see Chap. 15). Apart from financial remittances, social remittances (acquired skill, knowledge, and confidence) is also extremely important, and considerably under-researched.

Research shows that remittance-recipient households may not be using the financial resources in the best possible manner for improving adaptive capacity (Banerjee et al. 2017) although there is emerging evidence of the potential of certain types of remittances to contribute to adaptive capacity building in certain socio-economic contexts (see Chap. 15). Governments have a critical role in creating enabling conditions in origin communities through the promotion of opportunities for skill-building, entrepreneurship and livelihood diversification, and complementing such interventions with investment for improving the required economic infrastructure.

\footnotetext{
${ }^{26} \mathrm{http}: / /$ sakchyam.com.np/first-weather-index-insurance-productlaunched-in-nepal-for-apple-farmers-of-jumla/.

${ }^{27} \mathrm{https}$ ://cdkn.org/project/disaster-risk-insurance-for-vulnerablecommunities-in-pakistan/?loclang=en_gb.
}

\subsection{The Way Forward-Key Areas for Priority Action by HKH Country Governments}

Building on the lessons of this assessment exercise, this section puts forward an agenda for action for $\mathrm{HKH}$ countries. Opportunities do exist for a scaled-up, inclusive, and more comprehensive adaptation response in the HKH. This assessment suggests that the way forward should, among other things, include: (a) greater regional cooperation among $\mathrm{HKH}$ countries in areas such as DRR and food security; (b) stronger integration of adaptation in national development plans and programmes; (c) convergence of adaptation, DRR, SDGs, and resilience-building priorities; (d) investment for generating science-based climate information and knowledge services, creating knowledge networks, and boosting climate literacy; (e) promoting policy experimentation through adaptation pilots; (f) building institutional capacity on adaptive governance; and (g) engaging with private business.

\subsubsection{Regional Cooperation on Adaptation Is Essential}

Climate change impacts do not recognize national boundaries, and for the $\mathrm{HKH}$ - which shares so many resource systems - there can be significant cross-border implications with the potential to induce political instability and conflict at the regional level. Adaptation to the impacts of climate change can be viewed as a "regional public good" (Sandler 1998) and therefore justifies the call for greater cooperation among HKH countries. Even though upstream-downstream linkages between mountains and plains provide a strong basis for regional cooperation, presently there are very few examples of cross-country adaptation projects or programmes from the HKH (Sud et al. 2015). Among the South Asian riparian countries, enhanced regional collaboration for undertaking integrated scientific research, policy making, and implementation of cross-country adaptation measures has been frequently cited as essential (Viviroli et al. 2011; $\mathrm{Xu}$ et al. 2009).

There is scope to structure cooperation among $\mathrm{HKH}$ countries around the complete food-water-energy nexus (Rasul 2014). The Climate Summit for a Living Himalayas held in Bhutan in 2011 produced a regional Framework of Cooperation in which the agreed areas of cooperation included food security, natural freshwater systems of the Himalaya, biodiversity, and energy security. However, there has been no follow-up action or movement since the summit, which is indicative of the challenges remaining in implementing regional cooperative action on adaptation. 
Initiatives for regional cooperation can take advantage of some global processes as well. The UNFCCC's Lima Adaptation Knowledge Initiative is being implemented through its Nairobi Work Programme in collaboration with UN Environment and has taken steps to foster regional cooperation for identifying "priority knowledge gaps" for vulnerable subregions, and soliciting partnerships and cooperation in bridging knowledge gaps. This can be taken forward to stimulate stronger and more effective knowledge-based partnerships for adaptation among $\mathrm{HKH}$ countries.

A transformative stimulus from the global regime would be to allow global adaptation funding mechanisms to put in place funding instruments that can accommodate multi-country, transboundary, and regional adaptation action proposals. At the regional level, a potential mechanism could be the SAARC (South Asian Association for Regional Cooperation) Development Fund, and efforts should be made to explore the potential of SAARC in initiating a funding instrument that sets an example in bridging this critical funding gap.

\subsubsection{Stronger Integration of Adaptation in Development Plans and Programmes}

Given the diverse socioeconomic and biophysical variability across the HKH, scaling up adaptation to achieve transformative results is a huge challenge. It is therefore important for policy makers to embed adaptation to climate change in ongoing large-scale development-based activities. The NAP process and associated funding from the Green Climate Fund is likely to be helpful in this regard.

While aiming for an integrated approach, it is still necessary (though difficult and politically contentious) to retain the distinction between adaptation and development, to prevent diversion of adaptation investments to conventional development activities, as this potentially could lead to maladaptation (Ayres and Huq 2009; Ericksen et al. 2011). Bundling adaptation with traditional development funds would not be desirable from an operational point of view, since the mandate for the latter is too general, and tracking adaptation spending is likely to become a challenge. This approach of distinguishing additional climate change risks or additional environmental benefits has long been practised in the financing of projects by the GEF, where baseline activities need to be demonstrated and additional financing is provided only for the incremental cost of climate change or other environmental action.

\subsubsection{Convergence of Adaptation, DRR, SDGs, and Resilience-Building Priorities}

Climate change adaptation is identified as the cross-cutting priority with clear linkages to DRR, SDGs, and resilience building in most of the national policies and plans in the $\mathrm{HKH}$ that highlight the importance of greater integration. Those developing countries in the process of preparing NAPs and the countries that already have NAPA (like Nepal) have clearly indicated the need to link climate change adaptation with DRR and SDG priorities. In addition to the policies and plans, several adaptation initiatives in the region have piloted projects to facilitate the integration of climate change with DRR and SDGs.

Overarching national polices and frameworks, which can translate the idea of integration of climate change adaptation, DRR, and SDG into action, need to be developed. This will allow the national HKH governments to strategically think of policy, legal, and financial instruments that can facilitate convergence of the three.

\subsubsection{Investing to Enhance Synergies Between CBA and EBA}

While there is considerable focus on CBA, many EBA projects also exist around the world, including several in the HKH. A recent example is the GEF-SCCF-funded project Enhancing Capacity, Knowledge and Technology Support to Build Climate Resilience of Vulnerable Developing Countries, which has been recognized as the "first mover" in catalysing global collaborations on EBA in the context of South-South cooperation. It is a joint initiative between UNEP and the NDRC of China, consisting of concrete, on-the-ground EBA interventions in Seychelles, Nepal, and Mauritania, representing coastal, mountain, and arid/semi-arid ecosystems, respectively. Another example is the German-funded mountain EBA, which pilots in three mountainous countries: Nepal, Peru, and Uganda (UNDP 2015). Revi et al. (2014:539) provide examples in their global assessment, concluding that EBA is a "key contributor to urban resilience".

These initiatives have demonstrated the significant potential of an EBA approach for addressing climate change in the HKH. Since trade-offs between competing demands for ecosystem services are becoming increasingly significant, strong political leadership and optimal investment are required to enhance the synergies between EBA and other approaches. 


\subsubsection{Generating New Knowledge and Boosting Climate Literacy}

The adaptation policies and plans of all HKH countries emphasize generating science-based climate information, knowledge, and services to enhance the resilience of climate-sensitive sectors and vulnerable households. For example, in Myanmar and Bhutan, their respective NAPAs have identified a lack of locally usable knowledge and information on weather and seasonal forecasting to assist farm production operations. The NAPA of Afghanistan also identifies lack of empirical data on the extent and impact of desertification, thus hindering effective climate change adaptation. The problem of sparse data is fundamental in mountains, a part of the planet that also has limited infrastructure to generate climate data in the first place. Evidence-based decision making on adaptation warrants greater efforts towards strategic knowledge generation and communication through knowledge networks (for example, the Indian Network for Climate Change Assessment, Himalayan University Consortium) and knowledge management platforms.

In general, across the HKH, people's access to climate change information, knowledge, and services continues to be severely limited. The opportunity, however, lies in the fact that there are strong community networks to exchange information, knowledge, and skills relevant to climate change risk identification and adaptation (MoSTE 2015). For example, in Pakistan, a national-level alliance for climate adaptation comprising almost 200 local-level community organizations has been in existence since 2010. This has contributed to the awareness of local organizations and communities of issues related to climate change. ${ }^{28}$ Similar networks can be encouraged and supported in other $\mathrm{HKH}$ countries. This has to be accompanied by sustained efforts to promote climate literacy among the general public, which would require massive awareness campaigns, incorporation of climate change issues into the educational curriculum, and active engagement of the media.

\subsubsection{A Policy Environment for Social Learning}

Responding to novel situations requires the capacity to learn. Social learning plays a critical role in building adaptiveness in natural resource management (Lebel et al. 2010) and enabling transitions (Tschakert and Dietrich 2010). Policy experimentation, including piloting, is important in enabling social learning to overcome system lock-in and facilitate restructuring of existing social-technical systems for changes in norms, values, goals, processes, and actors (O'Brien

\footnotetext{
${ }^{28} \mathrm{http} / / / w w w . l e a d . o r g . p k / l e a d / P a g e s / n a c a . a s p x$.
}

et al. 2012). In discussing the example of specific water resource management pilots such as improved watermill and spring recharging in the Garhwal Himalaya, Uttarakhand, Agarwal (2013) argues that adaptation policies in the Himalayan states should encourage the development and adoption of replicable and scalable models of conservation of natural resources and livelihood support, based on decentralized planning.

\subsubsection{Building Institutions and Capabilities}

Effective adaptation requires enhancing adaptive capacity: this includes, among other things, change in institutions and institutional processes for better governance. The transformation of local institutions requires targeted resources for human capacity building as well as for setting up technology-enabled decision support systems. Stakeholder partnerships involving communities and local line agencies of the government will play a crucial role in effective adaptation outcomes. Since in mountainous terrain the reach of line agencies is limited when it comes to providing extension services, one approach would be to leverage existing community networks for the purpose. Social capital is one of the factors that is generally associated with mountain people's ability to recover early from disasters (Mishra et al. 2017b) and this can be considered as an asset when planning for adaptation interventions. Local (and national) agencies of the government are receptive to scaling up interventions by NGOs if tangible results can be demonstrated, and more so when communities advocate the benefit of such interventions and seek clear, focused support.

Local governance organizations, which have accommodated and legitimized customary institutions to formulate strategies for local natural resources, can take the role of bridging organizations in South Asia. One such example is the Dzumsa in Sikkim (India), which is an administrative unit continuing with the traditions of chiefdom. It regulates the migratory pattern for agro-pastoralists in the area, as well as governing other aspects like benefit sharing from different livelihood activities, social conduct, and cultural practices. It reserves certain pastures from grazing during seasons of normal snowfall and levies fines as an instrument of regulation. However, during seasons of erratic snowfall when local predictions cannot be successfully applied, the reserved pastures are made accessible for convenience of the agro-pastoralists. Such local governance institutions can fit between resource-using communities, civil society, local universities and technical institutes, government departments, and elected representatives.

Planned adaptation in the HKH will essentially require a mix of policy responses that consider a range of options from incremental to adaptive and potentially to 
transformative strategies. Given that climate uncertainty cannot be reduced completely, it is critical to deploy a decision-making framework to identify a suite of policy options instead of an optimal or best solution (Hallegatte et al. 2012; Smith et al. 2010). Conditions of "surprise" might offer little or no scope for decision makers to respond from history or experience (Lempert et al. 2003; Walker et al. 2010). The concept of adaptive policy making (policies adapt over time as conditions change and learning takes place) has received much attention in the past decade as a useful approach to policy formulation under uncertainty (Swanson and Bhadwal 2009). Capabilities required for adaptive governance need to be created in institutions at all levels of governance in $\mathrm{HKH}$ countries.

\subsubsection{Engaging with Private Business}

Business can become a partner in scaling up adaptation efficiently. There is considerable scope for attracting private finance to adaptation, provided the risks and transaction costs of such investments can be managed. Business looks for profits and scalability, and thus tends to be restricted to regions with a large business presence, market potential, and investment climate sustainability (Chin 2014). Since adaptation is about helping the vulnerable, with a focus on poor and marginal communities, novel models of public-private partnerships are required. Apart from protecting current operations, new revenue streams can be identified, such as ICT and insurance. At the same time local enterprises will need to be supported, not just big business.

Corporate social responsibility can play a very powerful role in building infrastructure and human capital. For example, Google has provided funding for disease outbreak monitoring in Myanmar, and the Rockefeller Foundation is working to build urban resilience in a number of $\mathrm{HKH}$ cities (Shimla, Shillong, Guwahati, and Leh) through the Asian Climate Cities Resilience Network (WRI 2009).

\subsubsection{Engaging with the Emerging Policy Regime on Loss and Damage}

Under the UNFCCC a new policy regime to prepare for inevitable losses and damage is covered under the Warsaw International Mechanism on Loss and Damage (L\&D) from Climate Change established in November 2013, and subsequently under the Paris Agreement. Policy makers within the UNFCCC are potentially planning to introduce a climate insurance scheme for highly vulnerable countries (Surminski and Oramas-Dorta 2014). The L\&D mechanism is premised on the existence of a residual policy gap between climate change adaptation, DRR, and current social protection and risk transfer mechanisms, ${ }^{29}$ wherein climate change may generate conditions that cannot be mitigated, adapted to, or insured against (Dow et al. 2013). Thus, for instance, studies have categorically found that existing adaptation measures are insufficient to avoid potential L\&D from weather variability in Bhutan (Kusters and Wangdi 2013) and flooding in Nepal (Bauer 2013).

Although efforts are being made by government agencies to estimate post-disaster L\&D, there is still controversy over the definition and estimation methodology (Birkmann and Welle 2015). Even though the direction is unclear at the moment, this assessment feels that it is potentially beneficial for HKH countries to stay engaged with the L\&D process.

\section{References}

ADB. (2015). Addressing climate change risks, disasters, and adaptation in the People's Republic of China. Mandaluyong City, Philippines: Asian Development Bank.

ADB. (2014). Climate risks in the SAARC region: Ways to address the social, economic \& environmental challenges. Draft report for SAARC. Mandaluyong City, Philippines: Asian Development Bank. ADB. (2013). Regional economics of climate change in South Asia: adaptation and impact assessment. Manila: Asian Development Bank.

ADB. (2012). Addressing Climate Change and Migration in Asia and the Pacific. Mandaluyong City, Philippines: Asian Development Bank.

Adger, W. N., Agrawala, S., Mirza, M. M. Q., Conde, C., O’Brien, K., Pulhin, J., et al. (2007). Assessment of adaptation practices, options, constraints and capacity. In M. L. Parry, O. F. Canziani, J. P. Palutikof, P. J. van der Linden \& C. E. Hanson, (Eds.), Climate change 2007: Impacts, adaptation and vulnerability. Contribution of working group II to the fourth assessment report of the intergovernmental panel on climate change. Cambridge University Press, Cambridge, UK, 717-743.

Agarwal, S. K. (2013). Emerging technological intervention models with scalable solutions for adaptation to climate change and livelihood Gains in Indian Himalayan Region: Case studies on action research at the grassroots level. In S. Nautiyal et al. (Eds.), Knowledge Systems of Societies for Adaptation and Mitigation of Impacts of Climate Change, Environmental Science and Engineering. Berlin, Heidelberg: Springer. https://doi.org/10.1007/978-3-642-36143-2_33.

Agrawal, A. (2008). The role of local institutions in adaptation to climate change. Paper prepared for the social dimensions of climate change, social development department, The World Bank, Washington, DC, March 5-6, 2008. http://siteresources.worldbank.org/ EXTSOCIALDEVELOPMENT/Resources/updated SDCCWorkingPaper_LocalInstitutions.pdf.

Ahmed, A. U. (Ed.). (2010). Reducing vulnerability to climate change: The pioneering example of community based adaptation in Bangladesh, centre for global change (CGC) and CARE Bangladesh, Dhaka (p. 156).

\footnotetext{
${ }^{29}$ As things stand now, the Social Protection Index (SPI) for South Asia, 0.061, is the lowest of any region. Countries such as Bangladesh, Bhutan, and India spend less than $2 \%$ of GDP on social protection and have relatively low SPIs of 0.051 or lower. Nepal does moderately better, despite being a low-income country, with an SPI of 0.068 and spending $2.1 \%$ of GDP on social protection (ADB 2013).
} 
Ahmed, A. U., Appadurai, N., \& Neelormi, S. (2018). Status of climate change adaptation in South Asia region. In M. Alam, J. Lee, \& P. Sawhney (Eds.), Status of climate change adaptation in Asia and the Pacific. Switzerland: Springer. (in press).

Ahmed, M., \& Suphachalasai, S. (2014). Assessing the costs of climate change and adaptation in South Asia. Mandaluyong City, Philippines: Asian Development Bank.

Ahmed, S., \& Fajber, E. (2009). Engendering adaptation to climate variability Gujarat, India. Gender \& Development, 17(1), 33-50.

Appadurai, A. N., Chaudhury, C., Dinshaw, A., Ginoya, N., McGray, H., Rangwala, L., et al. (2015). Scaling success: Lessons from adaptation pilots in the rainfed regions of India (p. 112). Washington DC: World Resources Institute.

Aryal, S., Maraseni, T. N., \& Cockfield, G. (2014). Sustainability of transhumance grazing systems under socio-economic threats in Langtang, Nepal. Journal of Mountain Science, 11(4), 1023-1034.

Ayres, J., \& Huq, S. (2009). Supporting adaptation to climate change: what role for ODA? Development Policy Review, 27(6), 675-692.

Banerjee, S., Kniveton, D., Black, R., Bisht, S., Das, P., \& Tuladhar, S. (2017). Does financial remittance build household level adaptive capacity? A case study of the flood affected households of Upper Assam in India. KNOMAD Working Paper 18.

Banjade, M. R., \& Paudel, N. S. (2008). Mobile Pastoralism in Crisis: Challenges, conflicts and status of Pasture Tenure in Nepal Mountains. Journal of Forest and Livelihood, 7(1), 49-57.

Barua, A., Katyaini, S., Mili, B., \& Gooch, P. (2014). Climate change and poverty: Building resilience of rural mountain communities in south Sikkim, eastern Himalaya, India. Regional Environmental Change, 14, 267-280.

Bauer, K. (2013). Are preventive and coping measures enough to avoid loss and damage from flooding in Udayapur district, Nepal? International Journal of Global Warming, 5(4), 433-451.

Bawa, K. S., Balachander, G., \& Raven, P. (2008). A case of new institutions. Science, 319, 136.

Bhatta, K. P., Chaudhary, P., Khattri-Chhetri, A., Thapa, K., Rana, R. B., Gurung, D., et al. (2016). Scaling-up climate smart agriculture in Nepal-Technology identification and piloting methodology report. Local initiatives for biodiversity, research, and development (LI-BIRD) and the consultative group for international agricultural research's (CGIAR) Research program on climate change, agriculture, and food security (CCAFS), Kaski, Nepal. Birkmann, J., Garschagen, M., Kraas, F., \& Quang, N. (2010). Adaptive urban governance: new challenges for the second generation of urban adaptation strategies to climate change. Sustainability Science, 5 (2), 185-206. http://dx.doi.org/10.1007/s11625-010-0111-3.

Birkmann, J., \& Welle, T. (2015). Assessing the risk of loss and damage: Exposure, vulnerability and risk to climate related hazards for different country classifications. International Journal of Global Warming, 8(2), 191-212.

Brooks, N., \& Adger, W. N. (2005). Assessing and enhancing adaptive capacity. In B. Lim, E. SpangerSiegfried, I. Burton, E. L. Malone, $\&$ S. Huq (Eds.), Adaptation policy frameworks for climate change (pp. 165-182). New York, NY: Cambridge University Press.

Brown, T. (1994). Livelihood, land and local institutions. a report on the findings of the WWF feasibility study for the conservation of the Kanchen-Junga Area. WWF Nepal program report series 4. Kathmandu: World Wildlife Fund (WWF).

Cameron, E., Shine, T., \& Bevins, W. (2013). Climate justice: Equity and justice informing a new climate agreement. Working paper. World Resources Institute, Washington DC and Mary Robinson Foundation-Climate Justice, Dublin. Retrieved October 7, 2016 from, http://www.wri.org/sites/default/files/climate_justice_equity_ and_justice_informing_a_new_climate_agreement.pdf.

Cao, J., Yeh, E. T., Holden, N. M., Qin, Y., \& Ren, Z. (2013). The roles of overgrazing, climate change and policy as drivers of degradation of China's grasslands. Nomadic Peoples, 17(2), 82-101. https://doi. org/10.3167/np.2013.170207.

Chambwera, M., Heal, G., Dubeux, C., Hallegatte, S., Leclerc, L., Markandya, B. A., et al. (2014) Economics of adaptation. In C. B. Field, V. R. Barros, D. J. Dokken, K. J. Mach, M. D. Mastrandrea, T. E. Bilir, M. Chatterjee, K. L. Ebi, Y. O. Estrada, R. C. Genova, B. Girma, E. S. Kissel, A. N. Levy, S. MacCracken, P. R. Mastrandrea, \& L. L. White (eds.), Climate change 2014: Impacts, adaptation, and vulnerability. Part A: Global and sectoral aspects. Contribution of working group II to the fifth assessment report of the intergovernmental panel on climate change (pp. 945-977). Cambridge, UK and New York, NY, USA: Cambridge University Press.

Chatterjee, R., \& Shaw, R. (2015). Role of regional organizations for enhancing private sector involvement in disaster risk reduction in developing Asia. In Disaster management and privates.

Chaudhury, A. S., Sova, C. A., Rasheed, T., Thornton, T. F., Baral, P., \& Zeb, A. (2014). Deconstructing local adaptation plans for action (LAPAs)-Analysis of Nepal and Pakistan LAPA initiatives. Working paper no. 67. CGIAR Research Program on Climate Change, Agriculture and Food Security (CCAFS), Copenhagen, Denmark. www.ccafs.cgiar.org.

Chaudhary, P. (2011). Transboundary conservation in Kangchenjunga landscape in the Eastern Himalayas. Graduate Doctoral Dissertations. Paper 61. http://scholarworks.umb.edu/doctoral_dissertations/61.

Chhetri, N., Chaudhary, P., Tiwari, P. R., \& Yadaw, R. B. (2012). Institutional and technological innovation: Understanding agricultural adaptation to climate change in Nepal. Applied Geography, 33, 142-150. Chetri D. K., Nepali Karki, D. B., Sah, R. \& Devkota N. R. (2011). Transhumance effect on husbandry practices and physiological attributes of Chauri (Yak-Cattle) in Rasuwa District. Our Nature, 9, 128-137.

Chettri, N., Thapa, R., \& Shakya, B. (2007). Participatory conservation planning in Kangchenjunga transboundary biodiversity conservation landscape. Tropical Ecology, 48, 163-176.

Chin, C. (2014). Time for business partnerships in the Himalayas. https://www.thethirdpole.net/2014/01/27/time-for-businesspartnerships-in-the-himalayas/.

Christensen, K., Raihan, S., Ahsan, R., Uddin, A. M. N., Ahmed, C. S., \& Wright, H. (2012). Ensuring access for the climate vulnerable in Bangladesh: Financing local adaptation. ActionAid Bangladesh $(A A B)$, Action research for community adaptation in Bangladesh (ARCAB), Bangladesh centre for advanced studies (BCAS), and international centre for climate change and development (ICC$C A D$ ), $A A B$, Dhaka, Bangladesh (126 pp).

Davis, M., \& Li, L. (2013). Understanding the policy contexts for mainstreaming climate change in Bhutan and Nepal: A synthesis. Regional climate change adaptation knowledge platform for Asia, Partner Report Series No. 10. Bangkok: Stockholm Environment Institute. www.asiapacificadapt.net or www.weADAPT.org.

Dodman, D., \& Mitlin, D. (2013). Challenges for community-based adaptation: Discovering the potential for transformation. Journal of International Development, 25(5), 640-659.

Dow, K., Berkhout, F., Preston, B. L., Klein, R. J. T., Midgely, G., \& Shaw, M. R. (2013). Limits to adaptation. Nature Climate Change, 3, 305-307. https://doi.org/10.1038/nclimate1847.

Eriksen, S., Aldunce, P., Bahinipati, C. S., Martins, R., Sygna, L., Ulsrud, K., et al. (2011). When not every response to climate 
change is a good one: Identifying principles for sustainable adaptation. Climate and Development, 3(1), 7-20.

FAO. (2010). Climate smart agriculture: Policies, practices and financing for food security, adaptation, and mitigation. Food and agriculture organization (FAO) of the United Nations, Rome, Italy.

Fenton, A., Gallagher, D., Wright, H., Huq, S., \& Nyandiga, C. (2014). Up-scaling finance for community-based adaptation. Climate and Development, 6(4), 388-397.

Ford, J.D., Berrang-Ford, L., Bunce, A., McKay, C., Irwin, M., \& Pearce, T. (2014). The current status of climate change adaptation policy and practice in Africa and Asia. Regional Environmental Change. https://doi.org/10.1007/s10113-014-0648-2.

Garg, A., Mishra, V., \& Dholakia, H. (2015). Climate change and India: Adaptation gap (2015) - A preliminary assessment. Working paper of Indian institute of management Ahmedabad (IIMA) W. P. No. 2015-11-01.

GIZ. (2015). The role of the private sector to scale-up climate finance in India: Final report; international climate initiative/German federal ministry of the environment.

Gioli, G., Khan, T., Bisht, S., \& Scheffran, J. (2014). Migration as an adaptation strategy and its gendered implications: A case study from the Upper Indus Basin. Mountain Research and Development, 34 (3), 255-265.

Gupta, N., Mishra, A., Agrawal, N. K. \& Satapathy, S. (2018). Inter-State cooperation to address climate change adaptation in the Indian Himalayan region - need of the hour. Economic and Political Weekly, LIII(12), 35-40, March 24.

Gurung, G. B., Pande, D. P., \& Khanal, N. P. (2014). Riverbed vegetable farming for enhancing livelihoods of people: a case study in the Tarai region of Nepal. Communities and livelihood strategies in developing countries (pp. 97-108). Japan: Springer.

Gyawali, S., Sthapit, B. R., Bhandari, B., Shrestha, P., Joshi, B. K., Mudwori, A., et al. (2006). Participatory plant breeding: A strategy of on-farm conservation and improvement of landraces. In: B. R. Sthapit \& Gauchan D. (Eds.), Proceedings of a national symposium, 18-19 July 2006, Kathmandu, Nepal (pp 164-173). On-farm Management of Agricultural Biodiversity in Nepal: Lessons Learned. Nepal Agricultural Research Council, LIBIRD, Bioversity and IDRC.

Hallegatte, S., Shah, A., Lempert, R., Brown, C., \& Gill, S. (2012). Investment decision making under deep uncertainty-application to climate change. Policy research working paper series 6193, The World Bank.

Hijioka, Y., Lin, E., Pereira, J. J., Corlett, R. T., Cui, X., Insarov, G. E., et al. (2014). Asia. In V. R. Barros, C. B. Field, D. J. Dokken, M. D. Mastrandrea, K. J. Mach, T. E. Bilir, M. Chatterjee, K. L. Ebi, Y. O. Estrada, R. C. Genova, B. Girma, E. S. Kissel, A. N. Levy, S. MacCracken, P. R. Mastrandrea \& L. L. White (eds.) Climate change 2014: Impacts, adaptation, and vulnerability. Part B: Regional aspects. Contribution of working group ii to the fifth assessment report of the intergovernmental panel on climate change (pp. 1327-1370). Cambridge, UK and New York, NY, USA: Cambridge University Press.

ICIMOD. (2015). http://lib.icimod.org/record/30770/files/CSV15.pdf.

ICIMOD. (2007). http://lib.icimod.org/record/22140/files/attachment_ 143.pdf.

IFC. (2010). A strategy to engage the private sector in climate change adaptation in Bangladesh; Study carried out by Asian Tiger Capital Partners. Ingty, T., \& Bawa, K. S. (2012) Climate change and indigenous people. In: M. L. Arrawatia \& S. Tambe (Eds.), Climate change in Sikkim: Patterns, impacts and initiatives (pp. 275-290). Gangtok, India: Published by: Information and Public Relations Department, Government of Sikkim.
Jodha, N. S. (1992). Mountain perspective and sustainability: a framework for development strategies. In N. S. Jodha, M. Banskota, \& T. Partap (Eds.), Sustainable mountain agriculture. New Delhi: Oxford and IBH Publishing.

Jones, L., \& Boyd, E. (2011). Exploring social barriers to adaptation: Insights from Western Nepal. Global Environmental Change, 21, $1262-1274$.

Jones, L., Carabine, E., \& Schipper, L. (2015). (Re) Conceptualising maladaptation in policy and practice: Towards an evaluative framework. PRISE working paper. London: Overseas Development Institute. http://prise.odi.org/wp-content/uploads/2015/06/ Reconceptualising-maladaptation.pdf.

Kelkar, U., Narula, K. K., Sharma, V. P., \& Chandna, U. (2008). Vulnerability and adaptation to climate variability and water stress in Uttarakhand State, India. Global Environmental Change, 18, 564-574.

Khattri, A., Parameshwar, D., \& Pellech, S. (2010). Opportunities for private sector engagement in Urban climate change resilience building (p. 94). Bangkok, Thailand: Rockefeller Foundation.

Khatri, N. K. (2008). Traditional practices and customary Laws of the Kirat people of Eastern Nepal and comparison with Nepal's statutory Laws. In N. Chettri, B. Shakya, \& E. Sharma (Eds.), Biodiversity conservation in the Kanchenjunga landscape. Kathmandu, Nepal: International Center for Integrated Mountain Development (ICIMOD).

Kreutzmann, H. (2011). Scarcity within opulence: Water management in the Karakoram Mountains revisited. Journal of Mountain Science, 8(4), 525-534.

Kusters, K., \& Wangdi, N. (2013). The costs of adaptation: Changes in water availability and farmers' responses in Punakha district, Bhutan. The International Journal of Global Warming, 5(4), 387-399.

Lempert, R. J., Popper, S. W., \& Bankes, S. C. (2003). Shaping the next one hundred years: New methods for quantitative, long-term policy analysis. Santa Monica, CA: RAND.

Li, L., Fei, X., Xu, J., \& Slater, H. (2012), Scoping assessment of knowledge needs in climate change adaptation in China, adaptation knowledge platform, partner report series no. 2. Bangkok: Stockholm Environment Institute. http://www.sei-inter.

Li, W., \& Huntsinger, L. (2011). China's grassland contract policy and its impacts on herder ability to benefit in Inner Mongolia: tragic feedbacks. Ecology and Society, 16(2), 1. www.ecologyandsociety. org/vol16/iss2/art1/.

LI-BIRD. (2015). Scaling up climate smart agriculture in Nepal. Project brochure. Pokhara, Nepal: LI-BIRD.

Maharjan, S. K., \& Maharjan, K. L. (2017). Review of climate policies and roles of institutions in the policy formulation and implementation of adaptation plans and strategies in Nepal. Journal of International Development and Cooperation, 23(1 \& 2), 41-54.

Mainlay, J., \& Tan, S. F. (2012). Mainstreaming gender and climate change in Nepal. IIED climate change working paper no. 2. London: International Institute for Environment and Development (IIED).

Manandhar, S., Pandey, V. P., Ishidaira, H., \& Kazama, F. (2012). Perturbation study of climate change impacts in a snow-fed river basin. Hydrological Processes, 27(24), 3461-3474.

Mimura, N., Pulwarty, R. S, Duc, D. M., Elshinnawy, I., Redsteer, M. H., Huang, H. Q., et al. (2014). Adaptation planning and implementation. In C. B. Field, V. R. Barros, D. J. Dokken, K. J. Mach, M. D. Mastrandrea, T. E. Bilir, M. Chatterjee, K. L. Ebi, Y. O. Estrada, R. C. Genova, B. Girma, E. S. Kissel, A. N. Levy, S. MacCracken, P. R. Mastrandrea \& L. L. White (eds.) Climate change 2014: Impacts, adaptation, and vulnerability. Part A: Global and sectoral aspects. Contribution of working group II to the fifth assessment report of the intergovernmental panel on 
climate change (pp. 869-898). Cambridge, UK and New York, NY, USA: Cambridge University Pres.

Mishra, A., Agrawal, N. K., Thorup, G., Bisht, S., Lelkanger, I. C. P., \& Gupta, N. (2017a). Strengthening women's roles as risk and resource managers at the frontline of climate change, Adaptation Solution Brief 1. Kathmandu: ICIMOD. http://lib.icimod.org/record/ 32584/files/icimodASB.pdf.

Mishra, A., Ghate, R., Maharjan, A., Gurung, J., Pathak, G., \& Upraity, A. (2017b). Building ex ante resilience of disaster-exposed mountain communities: Drawing insights from the Nepal earthquake recovery, International Journal of Disaster Risk Reduction, 22, 167-178. Elsevier. http://dx.doi.org/10.1016/j.ijdrr.2017.03.008.

Moors, E. J., Stoffel, M. (2013). Changing monsoon patterns, snow and glacial melt, its impacts and adaptation options in northern India: Synthesis. Science of the Total Environment. http://dx.doi.org/10. 1016/j.scitotenv.2013.11.058.

MoCC. (2012). National climate change policy. Government of Pakistan, ministry of climate change, Islamabad, Pakistan. Retrieved October 20, 2016, from http://wp.cedha.net/wp-content/ uploads/2014/05/Pakistan-Naitonal-Climate-Change-Policy.pdf.

MoE. (2011). Climate change policy, 2011. Ministry of environment, government of Nepal, Kathmandu, Nepal. Retrieved October 20 2016, from http://www.climatenepal.org.np/main/?p=research\&sp= onlinelibrary\&opt $=$ detail $\& \mathrm{id}=419$.

MoEF. (2009). Bangladesh climate change strategy and action plan 2009. Ministry of environment and forests, government of the people's republic of Bangladesh, Dhaka, Bangladesh (xviii +76 pp.). Retrieved October 20, 2016, from http://www. climatechangecell.org.bd/Documents/climate_change_ strategy2009.pdf.

Moench, M., Khan, F., MacClune, K., Amman, C., Tran, P., \& Hawley, K. (2015). The sheltering from a gathering storm research team: Transforming vulnerability: Shelter, adaptation, and climate thresholds, climate and development. https://doi.org/10.1080/ 17565529.2015 .1067592$.

MoNERC. (2016). Myanmar climate change strategy and action plan. Naypyitaw, Myanmar: Final Draft.

MoSTE. (2015). Indigenous and local knowledge and practices for climate resilience in Nepal, mainstreaming climate change risk management in development, ministry of science, technology and environment (MoSTE), Kathmandu, Nepal.

Moktan, M. R., Norbu, L., Nirola, H., Dukpa, K., Rai, T. B., \& Dorji, R. (2008). Ecological and social aspects of transhumant herding in Bhutan. Mountain Research and Development, 28(1), 41-48.

Molden, D. J., Shrestha, A. B., Nepal, S., \& Immerzeel, W. W. (2016). Downstream implications of climate change in the Himalayas. Water security, climate change and sustainable development (pp. 65-82). Singapore: Springer.

Müller-Böker, U., \& Kollmair, M. (2000). Livelihood strategies and local perceptions of a new nature conservation project in Nepal: The Kanchenjunga conservation area project. Mountain Research and Development, 20, 324-331.

Nagoda, S., \& Nightingale, A. J. (2017). Participation and power in climate change adaptation policies: Vulnerability in food security programs in Nepal. World Development, 100, 85-93.

NAPCC. (2008). National action plan on climate change. Government of India, Prime Minister's Council on climate change. Retrieved October 20, 2016, from http://www.moef.nic.in/downloads/home/ Pg01-52.pdf.

NEC. (2011). Second national communication to UNFCCC. National environment commission, royal government of Bhutan, Thimphu.
Norbu, W., \& Kusters, K. (2012). The costs of adaptation in Punakha, Bhutan: Loss and damage associated with changing monsoon patterns, climate development knowledge network (CDKN). http:// loss-and-damage.net/download/6902.pdf.

Norse, D., Li, J., Jin, L., \& Zhang, Z. (2001). Environmental costs of rice production in China, lessons from Hunan and Hubei. Bethesda, MD: Aileen International Press.

O'Brien, K., Pelling, M., Patwardhan, A., Hallegatte, S., Maskrey, A. Oki, T., et al. (2012). Toward a sustainable and resilient future. In C. B. Field, V. Barros, T. F. Stocker, D. Qin, D. J. Dokken, K. L. Ebi, M. D. Mastrandrea, K. J. Mach, G.-K. Plattner, S. K. Allen, M. Tignor, \& P. M. Midgley (Eds.), Managing the risks of extreme events and disasters to advance climate change adaptation. A special report of working groups I and II of the intergovernmental panel on climate change (IPCC) (pp. 437-486). Cambridge, UK, and New York, NY, USA: Cambridge University Press.

Ojha, H. R., Ghimire, S., Pain, A., Nightingale, A., Khatri, D. B., \& Dhungana, H. (2015). Policy without politics: technocratic control of climate change adaptation policy making in Nepal Clim. Policy (pp. 415-433).

Onta, N., \& Resurreccion, B. P. (2011). The role of gender and caste in climate adaptation strategies in Nepal. Mountain Research and Development, 31(4), 351-356.

Ostrom, E. (1990). Governing the commons: the evolution of institutions for collective action (P. 280). Cambridge University Press.

Parikh, J., Upadhyay, D. K., \& Singh, T. (2012). Gender perspectives on climate change and human security in India: An analysis of national missions on climate change. Cadmus, 1(4), 180-186.

Park, J., \& Alam, M. (2015). Ecosystem-based Adaptation Planning in the Panchase Mountain Ecological Region. Hydro Nepal: Journal of Water, Energy and Environment., 17, 34-41.

Piya, L., Maharjan, K. L., \& Joshi, N. P. (2012). Comparison of adaptive capacity and adaptation practices in response to climate change and extremes among the Chepang households in rural Mid-Hills of Nepal. Journal of International Development and Cooperation, 18(4), 55-75.

Piya, L., Maharjan, K. L., \& Joshi, N. P. (2013). Determinants of adaptation practices to climate change by Chepang households in the rural Mid-Hills of Nepal. Regional Environmental Change, 2013(13), 437-447. https://doi.org/10.1007/s10113-012-0359-5.

Rasul, G. (2014). Food, water, and energy security in South Asia: A nexus perspective from the Hindu Kush Himalayan region. Environmental Science \& Policy, 39, 35-48.

Rasul, G., \& Sharma, B. (2016). The nexus approach to water-energyfood security: An option for adaptation to climate change. Climate Policy, 16(6), 682-702.

Regmi, B. R., \& Star, C. (2015). Exploring the policy environment for mainstreaming community based adaptation (CBA) in Nepal. International Journal of Climate Change Strategies and Management, 7(4), 423-441.

Regmi, B. R., Star, C., \& Filho, W. L. (2016). An overview of the opportunities and challenges of promoting climate change adaptation at the local level: A case study from a community adaptation planning in Nepal. Climatic Change, 138, 537-550. https://doi.org/ 10.1007/s10584-016-1765-3.

Revi, A., Satterthwaite, D. E., Aragón-Durand, F., Corfee-Morlot, J., Kiunsi, R. B .R., Pelling, M., Roberts, D. C., Solecki, W. (2014). Urban areas. In C. B. Field, V. R. Barros, D. J. Dokken, K. J. Mach, M. D. Mastrandrea, T. E. Bilir, M. Chatterjee, K. L. Ebi, Y. O. Estrada, R. C. Genova, B. Girma, E. S. Kissel, A. N. Levy, S. MacCracken, P. R. Mastrandrea, \& L. L. White (Eds.), Climate 
Change 2014: Impacts, Adaptation, and Vulnerability. Part A: Global and Sectoral Aspects. Contribution of Working Group II to the Fifth Assessment Report of the Intergovernmental Panel on Climate Change (pp. 535-612). Cambridge, UK and New York, NY, USA: Cambridge University Press.

Robledo, C., Clot, N., Hammill, A., \& Riché, B. (2012). The role of forest ecosystems in community-based coping strategies to climate hazards: Three examples from rural areas in Africa. Forest Policy and Economics, 24, 20-28.

Saito, N. (2012). Mainstreaming climate change adaptation in least developed countries in South and Southeast Asia. Mitigation Adaptation Strategies for Global Change, 18, 825-849.

Sandler, T. (1998). Global and regional public goods: a prognosis for collective action. Fiscal Studies, 19(3), 221-247.

Sherman, M. H., \& Ford, J. (2014). Stakeholder engagement in adaptation interventions: an evaluation of projects in developing nations. Climate Policy, 14(3), 417-441.

Shrestha, A. B., Agrawal, N. K., Alfthan, B., Bajracharya, S. R., Marechal, J., \& van Oort, B. (eds.). (2015). The Himalayan climate and water atlas: Impact of climate change on water resources in five of Asia's major river basins. ICIMOD, Grid-Arendal, and CICERO.

Shrestha, M. S., Grabs, W. E., \& Khadgi, V. R. (2015b). Establishment of a regional flood information system in the Hindu Kush Himalayas: Challenges and opportunities. International Journal of Water Resources Development, 31(2), 238-252.

Smit, B., \& Pilifosova, O. (2001). Adaptation to climate change in the context of sustainable development and equity. In J. J. Mcarthy, O. F. Canziani, N. A. Learty, D. J. Dokken, \& K. S. White (Eds.), Climate change 2001: Impacts, adaptation and vulnerability, international panel on climate change (pp. 877-912). Cambridge, UK and New York, USA: Cambridge University Press.

Smith, M. S., Horrocks, L., Harvey, A., \& Hamilton, C. (2010). Rethinking adaptation for a $4{ }^{\circ} \mathrm{C}$ world. Philosophical Transactions of the Royal Society, 2011.

Spires, M., Shackleton, S., \& Cundill, G. (2014). Barriers to implementing planned community based adaptation in developing countries: A systematic literature review. Climate and Development, 6(3), 277-287.

Su, Y., Lu, J., Manandhar, S., Ahmad A., \& Xu J. (2013). Policy and institutions in adaptation to climate change: Case study on tree crop diversity in China, Nepal, and Pakistan. ICIMOD working paper 2013/3.

Sud, R., Mishra, A., Varma, N., \& Bhadwal, S. (2015). Adaptation policy and practice in densely populated glacier-fed river basins of South Asia: a systematic review. Regional Environmental Change, 15, 825-836. https://doi.org/10.1007/s10113-014-0711-z.

Surminski, S., \& Oramas-Dorta, D. (2014). Flood insurance schemes and climate adaptation in developing countries. International Journal of Disaster Risk Reduction, 7, 154-164.

Swanson, D., \& Bhadwal, S. (Eds.). (2009). Creating adaptive policies: A guide for policymaking in an uncertain world. Ottawa: Sage, New Delhi/IDRC.

Tall, A., Hansen, J., Jay, A., Campbell, B., Kinyangi, J., Aggarwal, P. K., et al. (2014). Scaling up climate services for farmers: Mission possible. Learning from good practice in Africa and South Asia. $C C A F S$ report no. 13. Copenhagen: CGIAR research program on climate change, agriculture and food security (CCAFS). www. ccafs.cgiar.org.
Tanner, T. M., Mitchell, T., Polack, E., \& Guenther, B. (2008). Urban governance for adaptation: Assessing climate change resilience in Ten Asian Cities, IDS Working Paper 315. Brighton: IDS.

Tao, F., \& Zhang, Z. (2010). Adaptation of maize production to climate change in North China Plain: quantify the relative contributions of adaptation options. European Journal of Agronomy, 33, 103-116.

Task Force on Climate-related Financial Disclosures (TCFD). (2017). Final report of the task force on climate-related financial disclosures. Retrieved June 2017, from https://www.fsb-tcfd.org/wpcontent/uploads/2017/06/FINAL-TCFD-Report-062817.pdf.

Tiwari, P. C., \& Joshi, B. (2015). Local and regional institutions and environmental governance in Hindu Kush Himalaya. Environmental Science \& Policy, 49, 66-74.

Tschakert, P., \& Dietrich, K. A. (2010). Anticipatory learning for climate change adaptation and resilience. Ecology and Society, 15 (2), 11.

UNDP. (2015). Making the case for ecosystem-based adaptation: The Global Mountain EbA Programme in Nepal, Peru and Uganda. United Nations Development Programme, New York. http://www. pnuma.org/cambio_climatico/publicaciones/UNDP_(2015)-Mt_ EbA_report_FINAL2 web_vs(041215).pdf.

UNDP. (2012). Technical and social impact assessment: Reducing climate change-induced risk and vulnerabilities from glacial lake outburst floods in Punakha, Wangdue and Chamkhar Valleys.

UNEP. (2016). Adaptation gap report update, the united nations environment programme (UNEP), Nairobi, Kenya.

Varma, N., \& Mishra, A. (2017). Discourses, narratives and purposeful action- Unraveling the social-ecological complexity within Brahmaputra basin in India. Environmental Policy and Governance. https:// doi.org/10.1002/eet.1745.

Viviroli, D., Archer, D. R., Buytaert, W., Fowler, H. J., Greenwood, G. B., Hamlet, A. F., et al. (2011). Climate change and mountain water resources: overview and recommendations for research, management and policy. Hydrology and Earth System Sciences, 15(2), 471-504.

Walker, W., Marchau, V., \& Swanson, D. (2010). Addressing deep uncertainties using adaptive policies. Technological Forecasting \& Social Change, 77(6), Special Section 2.

Wamsler, C. (2007). Bridging the gaps: stakeholder-based strategies for risk reduction and financing for the urban poor. Environment \& Urbanization, 19(1), 115-142. https://doi.org/10.1177/ 0956247807077029 .

Wang, J., Huang, J., \& Rozelle, S. (2010). Climate change and China's agricultural sector: An overview of impacts, adaptation and mitigation, ICTSD-IPC platform on climate change, agriculture and trade, issue brief no. 5. In International Centre for Trade and Sustainable Development, Geneva, Switzerland, and International Food \& Agricultural Trade Policy Council, Washington, DC.

Wangdi, K.,. Singhasivanon, P., Silawan, T., Lawpoolsri, S., White, N. J., \& Kaewkungwal J. (2010). Development of temporal modelling for forecasting and prediction of malaria infections using time-series and ARIMAX analyses: A case study in endemic districts of Bhutan. Malaria Journal, 9(251), pp. 251-259.

WB. (2016). World Development Indicators database, World Bank, October 11, 2016

Wong, S. (2010). Elite capture or capture elites? Lessons from the 'counter-elite' and 'co-opt-elite' approaches in Bangladesh and Ghana (No. 2010, 82). Working paper//World Institute for Development Economics Research. 
WRI. (2009). http://pdf.wri.org/making_climate_your_business.pdf.

Xu, J., \& Grumbine, R. E. (2014). Integrating local hybrid knowledge and state support for climate change adaptation in the Asian Highlands. Climatic Change, 93-104.

Xu, J., Grumbine, R. E., Shrestha, A., Eriksson, M., Yang, X., Wang, Y., et al. (2009). The Melting Himalayas: Cascading effects of climate change on water, Biodiversity, and Livelihoods. Conservation Biology, 23(3), 520-530.

Yu, X., Jiang, L., Wang, J., Wang, L., Lei, G., \& Pittock, J. (2009). Freshwater management and climate change adaptation: Experiences from the central Yangtze in China. Climate and Development, $1,241-248$.
Open Access This chapter is licensed under the terms of the Creative Commons Attribution 4.0 International License (http:// creativecommons.org/licenses/by/4.0/), which permits use, sharing, adaptation, distribution and reproduction in any medium or format, as long as you give appropriate credit to the original author(s) and the source, provide a link to the Creative Commons license and indicate if changes were made.
The images or other third party material in this chapter are included in the chapter's Creative Commons license, unless indicated otherwise in a credit line to the material. If material is not included in the chapter's Creative Commons license and your intended use is not permitted by statutory regulation or exceeds the permitted use, you will need to obtain permission directly from the copyright holder. 